\title{
Phylogeny and phylogeography of Atlantic oyster species: evolutionary history, limited genetic connectivity and isolation by distance
}

\author{
C. Lazoski ${ }^{1}$, J. Gusmãoo ${ }^{1,2}$, P. Boudry ${ }^{3}$, A. M. Solé-Cava ${ }^{1, *}$ \\ ${ }^{1}$ Laboratório de Biodiversidade Molecular - Departamento de Genética, Instituto de Biologia, UFRJ, CCS, Bloco A, \\ sala A2-98, Ilha do Fundão, 21941-490 Rio de Janeiro, Brazil \\ ${ }^{2}$ Laboratório de Genética Marinha - Departamento de Genética, Instituto de Biologia Roberto Alcântara Gomes, UERJ, \\ Maracanã, 20550-900 Rio de Janeiro, Brazil \\ ${ }^{3}$ Ifremer, UMR M100 Physiologie et Ecophysiologie des Mollusques Marins, 29280 Plouzané, France
}

\begin{abstract}
The phylogenetic relationships between naturally occurring Atlantic Crassostrea oyster species were inferred through analyses of mitochondrial (cytochrome oxidase subunit I and 16S) and nuclear (second internal transcribed spacer) sequences. We also scored 15 allozyme loci on 422 oysters to study population structuring of C. rhizophorae and C. brasiliana along $9000 \mathrm{~km}$ of the Western Atlantic coastline. Despite morphological similarities, $C$. virginica was genetically more closely related to $C$. rhizophorae than to $C$. brasiliana. In contrast, $C$. paraibanensis was genetically indistinguishable from $C$. brasiliana, which is probably a junior synonym of the African C. gasar. Significant genetic differentiation between populations of C. rhizophorae and C. gasar were found along the Western Atlantic coast, supporting an isolation-by-distance pattern.
\end{abstract}

KEY WORDS: Population genetics - Biogeography $\cdot$ Allozymes $\cdot$ Cytochrome $c$ oxidase subunit I COI $\cdot 16 \mathrm{~S} \cdot$ Internal transcribed spacer $2 \cdot$ ITS-2

\section{INTRODUCTION}

Oysters are the world's most economically important mollusks, with a global average production of 4.6 million tons $\mathrm{yr}^{-1}$ (FAO 2010). In the Western Atlantic, oysters of the genus Crassostrea are the fourth largest marine fishery resource (average of 200000 tons $\mathrm{yr}^{-1}$; FAO 2010). The most heavily exploited species in the region are C. virginica (Gmelin, 1791), C. rhizophorae (Guilding, 1828) and the exotic C. gigas (Thünberg, 1793).

Phylogenetic studies have demonstrated the existence of 2 evolutionary lineages within the Crassostrea genus, one from the Atlantic and another from the Pacific, which could have been formed during the closure of the Tethys Seaway (Ó Foighil \& Taylor 2000). Molecular phylogenies of both nuclear and mitochondrial genomes have helped to clarify the taxonomic confusion of the Pacific Crassostrea species (Reece et al. 2008, Wu et al. 2010). On the other hand, the taxonomic status of Atlantic Crassostrea oysters is still confused: there is clear evidence for the existence of at least 2 oyster species along the Brazilian coast (Absher 1989, Ignacio et al. 2000), but 5 other nominal species have been cited for the area, regarded as native $(C$. virginica, Carriker \& Gaffney 1996; C. paraibanensis, Singarajah 1980) or invasive (C. gigas, Melo et al. 2010b; C. gasar Adanson, 1757, Lapègue et al. 2002; Crassostrea sp., Varela et al. 2007, Melo et al. 2010a) species. The correct identification of those oyster species is of paramount importance, because they are used in aquaculture and in biomonitoring studies (e.g. Rebelo et al. 2003), and may be under environmental threat (Carranza et al. 2009).

The uncertainty in the classification of Atlantic oyster species may have been caused in part by the great 
morphological and ecological similarities between Crassostrea brasiliana (Lamarck, 1819) and C. virginica. C. rhizophorae and C. brasiliana are also morphologically quite similar and have been considered synonyms in monographic studies of Brazilian mollusks (Rios 1994). This may have led some systematists to suggest that $C$. rhizophorae and $C$. brasiliana were morphotypes of a single species (C. virginica) (Harry 1985, Carriker \& Gaffney 1996).

Crassostrea rhizophorae is found in the intertidal zone, either attached to Rhizophora mangle roots or on rocks, from the Caribbean to the southern Atlantic (Santa Catarina State, Brazil) (Carriker \& Gaffney 1996). C. brasiliana usually attaches to rocks in infralittoral zones, and it is most abundant from southeastern Brazil (Espírito Santo State) to the more temperate regions in southern Brazil (Absher 1989). The species has also been observed in French Guyana (Lapègue et al. 2002) and in Venezuela (Hoover \& Gaffney 2005).

Besides the ecological differences, these oyster species can be distinguished by shell size, which is much larger in Crassostrea brasiliana (50 to $190 \mathrm{~mm}$ ) than in C. rhizophorae (20 to $65 \mathrm{~mm}$ ) (Absher 1989). However, this only holds true for adult specimens. Based on Lamarck's small-shelled holotype for C. brasiliana, Singarajah (1980) considered it a synonym of C. rhizophorae. Hence, he described the large oysters found in Paraíba State (northeastern Brazil) as a new species, C. paraibanensis (Singarajah 1980). However, other authors considered that this species might be synonymous with C. brasiliana (Rios 1994, Carriker \& Gaffney 1996).

Those taxonomic problems can also result from differing views on the degree of differentiation required to define a species in Crassostrea. Since the late 1970s, many studies have employed molecular methods to address the systematics and population genetics of Crassostrea species. For example, consistent genetic differences have been found between C. rhizophorae and C. virginica using allozyme (Buroker et al. 1979, Hedgecock \& Okazaki 1984) and ribosomal DNA data (Littlewood 1994), as well as between C. rhizophorae and C. brasiliana using morphology (Absher 1989), allozymes (Ignacio et al. 2000, Lazoski 2004) and mitochondrial $16 \mathrm{~S}$ or cytochrome $c$ oxidase subunit I (COI) data (Lapègue et al. 2002, Boudry et al. 2003, Lazoski 2004, Varela et al. 2007). In contrast, Lapègue et al. (2002) did not find any differences between $16 \mathrm{~S}$ sequences of West African C. gasar and South American Crassostrea specimens, which led them to suggest that $C$. brasiliana and C. gasar might be the same species (with $C$. brasiliana being a junior synonym of C. gasar). However, no molecular studies have compared $C$. virginica and C. brasiliana populations.

Although marine species with potentially high dispersal capability are believed to have high levels of gene flow, there are many examples showing the opposite (e.g. Palumbi 2003, Johansson et al. 2008), including studies of Crassostrea species (Hedgecock \& Okazaki 1984, Hare \& Avise 1998, Xiao et al. 2010). Population genetic studies have unveiled patterns of isolation by distance among oyster populations (Launey et al. 2002, Rose et al. 2006, Xiao et al. 2010), and are of great interest not only when addressing evolutionary and ecological processes but also as a basis for management and conservation of commercially important marine species.

In spite of the economic importance of Crassostrea oysters, no study has been carried out on the degree of genetic connectivity of their populations along the Western Atlantic. Moreover, the unresolved systematics of those species has confounded the compiled fishery statistics data (FAO 2010) for the Latin American coast, and the true geographic distribution of oyster species along this area is still uncertain (Singarajah 1980, Carriker \& Gaffney 1996, Ignacio et al. 2000, Lapègue et al. 2002, Varela et al. 2007).

In this paper, we compare Atlantic populations of Crassostrea by means of allozyme electrophoresis and analyses of nuclear (internal transcribed spacer 2, ITS-2) and mitochondrial (COI, 16S) sequences. Our objectives were to define the taxonomic boundaries among the Western Atlantic oysters, C. brasiliana, C. virginica, C. rhizophorae and C. paraibanensis, and to verify their actual distribution. We also compared the nuclear and mitochondrial gene sequences from specimens of $C$. brasiliana and the African C. gasar to resolve their taxonomic ambiguity. Additionally, we investigated the levels of genetic variation and the population structures in C. brasiliana and C. rhizophorae along $9000 \mathrm{~km}$ of the Western Atlantic coastline.

\section{MATERIALS AND METHODS}

Sampling. A total of 419 individuals, presumed to be either Crassostrea rhizophorae or C. brasiliana, were collected between May 1996 and February 2003 from 21 localities in Brazil and Panama (Table 1). Sixty-five samples of other Crassostrea species were also collected in the Gulf of Mexico (USA; $29^{\circ} 03^{\prime} \mathrm{N}_{;} 95^{\circ} 07^{\prime} \mathrm{W}$ : C. virginica, $\mathrm{N}=6$ ), Africa (Senegal; $14^{\circ} 10^{\prime} \mathrm{N}$; $16^{\circ} 51^{\prime} \mathrm{W}$ : C. gasar, $\mathrm{N}=7$; Lapègue et al. 2002) and Brazil (Itajaí; $26^{\circ} 55^{\prime} \mathrm{S} ; 48^{\circ} 38^{\prime} \mathrm{W}$ : hatchery of C. gigas, $\mathrm{N}=31$; and Mamanguape, $\mathrm{PB} 1,07^{\circ} 06^{\prime} \mathrm{S}$; $34^{\circ} 54^{\prime} \mathrm{W}$ : C. paraibanensis, $\mathrm{N}=21$ ) (Table 1, Fig. 1). Twenty-two individuals of $O s-$ trea sp. from Brazil (Sepetiba, RJ1, $22^{\circ} 58^{\prime} \mathrm{S}_{;} 43^{\circ} 42^{\prime} \mathrm{W}$; Picinguaba, SP1, 23 $22^{\prime} \mathrm{S} ; 44^{\circ} 50^{\prime} \mathrm{W}$ ) were used as an outgroup for the allozyme analysis. After collection, the oysters were transported (alive, in liquid $\mathrm{N}_{2}$ or in ethanol) to the laboratory, where they were identified morpholog- 
Table 1. Crassostrea rhizophorae and C. brasiliana. Sampling sites, coordinates and habitats for the putative Crassostrea rhizophorae and C. brasiliana collected. (i): intertidal zone; (s): subtidal zone. ${ }^{*}$ Samples available only for DNA analysis

\begin{tabular}{|c|c|c|c|c|}
\hline Sites & Coordinates & Habitat & $\begin{array}{l}\text { C. bra- } \\
\text { siliana }\end{array}$ & $\begin{array}{l}\text { C. rhizo- } \\
\text { phorae }\end{array}$ \\
\hline \multicolumn{5}{|l|}{ Panama } \\
\hline Panama (PAN) & $09^{\circ} 10^{\prime} \mathrm{N} ; 80^{\circ} 17^{\prime} \mathrm{W}$ & Rocks (i) & - & 14 \\
\hline \multicolumn{5}{|l|}{ Brazil } \\
\hline Belém (PA) & $01^{\circ} 25^{\prime} \mathrm{S}_{;} 48^{\circ} 28^{\prime} \mathrm{W}$ & Mangrove (i) & 12 & - \\
\hline Araioses (MA) & $02^{\circ} 53^{\prime} \mathrm{S} ; 41^{\circ} 54^{\prime} \mathrm{W}$ & Mangrove (i) & $12^{*}$ & - \\
\hline Parnaíba (PI) & $02^{\circ} 51^{\prime} \mathrm{S}_{;} 41^{\circ} 45^{\prime} \mathrm{W}$ & Rocks (i) & $5^{*}$ & - \\
\hline Fortaleza (CE) & $03^{\circ} 46^{\prime} \mathrm{S}_{;} 38^{\circ} 26^{\prime} \mathrm{W}$ & Rocks (i) & - & $12^{*}$ \\
\hline Natal (RN1) & $05^{\circ} 45^{\prime} \mathrm{S}_{;} 35^{\circ} 11^{\prime} \mathrm{W}$ & Mangrove (i) & - & 35 \\
\hline Natal (RN2) & $05^{\circ} 52^{\prime} \mathrm{S} ; 35^{\circ} 09^{\prime} \mathrm{W}$ & Rocks (i) & - & 20 \\
\hline Mamanguape (PB1) & $07^{\circ} 06^{\prime} \mathrm{S} ; 34^{\circ} 54^{\prime} \mathrm{W}$ & Mangrove (i) & 7 & 10 \\
\hline Cabo Branco (PB2) & $08^{\circ} 07^{\prime} \mathrm{S} ; 34^{\circ} 52^{\prime} \mathrm{W}$ & Mangrove (i) & - & 24 \\
\hline Recife (PE) & $08^{\circ} 46^{\prime} \mathrm{S} ; 34^{\circ} 56^{\prime} \mathrm{W}$ & Mangrove (i) & $24\left(1^{*}\right)$ & $1\left(3^{*}\right)$ \\
\hline Salvador (BA1) & $13^{\circ} 00^{\prime} \mathrm{S} ; 38^{\circ} 26^{\prime} \mathrm{W}$ & Rocks (i) & 20 & - \\
\hline Caravelas (BA2) & $17^{\circ} 44^{\prime} \mathrm{S} ; 39^{\circ} 15^{\prime} \mathrm{W}$ & Mangrove (i) & - & 30 \\
\hline Vitória (ES) & $20^{\circ} 18^{\prime} \mathrm{S} ; 40^{\circ} 17^{\prime} \mathrm{W}$ & Rocks (i) & - & $12^{*}$ \\
\hline Sepetiba (RJ1) & $22^{\circ} 58^{\prime} \mathrm{S} ; 43^{\circ} 42^{\prime} \mathrm{W}$ & Rocks (i) & - & 22 \\
\hline Guaratiba (RJ2) & $22^{\circ} 58^{\prime} \mathrm{S} ; 43^{\circ} 40^{\prime} \mathrm{W}$ & Mangrove (i) & - & $20^{*}$ \\
\hline Rio das Ostras (RJ3) & $22^{\circ} 31^{\prime} \mathrm{S} ; 41^{\circ} 56^{\prime} \mathrm{W}$ & Rocks (s) & $5^{*}$ & - \\
\hline Picinguaba (SP1) & $23^{\circ} 22^{\prime} \mathrm{S}_{;} 44^{\circ} 50^{\prime} \mathrm{W}$ & Rocks (i) & - & 10 \\
\hline Itanhaém (SP2) & $24^{\circ} 11^{\prime} \mathrm{S} ; 46^{\circ} 47^{\prime} \mathrm{W}$ & Mangrove (i) & 4 & - \\
\hline Cananéia (SP3) & $25^{\circ} 00^{\prime} \mathrm{S}_{;} 47^{\circ} 56^{\prime} \mathrm{W}$ & Rocks (s) & $7^{*}$ & - \\
\hline Paranaguá (PR1) & $25^{\circ} 32^{\prime} \mathrm{S}_{;} 48^{\circ} 22^{\prime} \mathrm{W}$ & Rocks (s) & 40 & - \\
\hline Paranaguá (PR1) & $25^{\circ} 32^{\prime} \mathrm{S} ; 48^{\circ} 22^{\prime} \mathrm{W}$ & Rocks (i) & - & 35 \\
\hline Guaratuba (PR2) & $25^{\circ} 51^{\prime} \mathrm{S} ; 48^{\circ} 35^{\prime} \mathrm{W}$ & Rocks (i) & 2 & 32 \\
\hline Total & & & 139 & 280 \\
\hline
\end{tabular}

ically (Absher 1989; Fig. 2), measured (shell height, length and depth), dissected, and stored in either liquid nitrogen or ethanol until required for genetic analyses.

Allozymes. Horizontal $12.5 \%$ starch gel electrophoresis was carried out as previously described (Ignacio et al. 2000). The 11 enzyme systems investigated and the 3 buffer systems used are summarized in Table 2. The enzyme systems were stained according to standard procedures (Manchenko 1994) and corresponded to a total of 15 allozyme loci.

DNA purification, amplification and sequencing. Total DNA purification was performed using a modified $1 \%$ $\mathrm{N}$-cetyl N,N,N-trimethylammonium bromide (CTAB) protocol $(2 \%$ CTAB, $20 \mathrm{mM}$ EDTA, $0.2 \% \quad \beta$-mercaptoethanol, $0.1 \mathrm{M}$ Tris, $1.4 \mathrm{mM} \mathrm{NaCl}$ ), followed by a sodium acetate- and isopropanol-induced precipitation step (Gusmão \& Solé-Cava 2002). Polymerase chain reactions (PCR) used approximately $10 \mathrm{ng}$ of template DNA, 1 unit of Taq polymerase (GE Life Sciences), $200 \mu \mathrm{M}$ each of the 4 dinucleo-

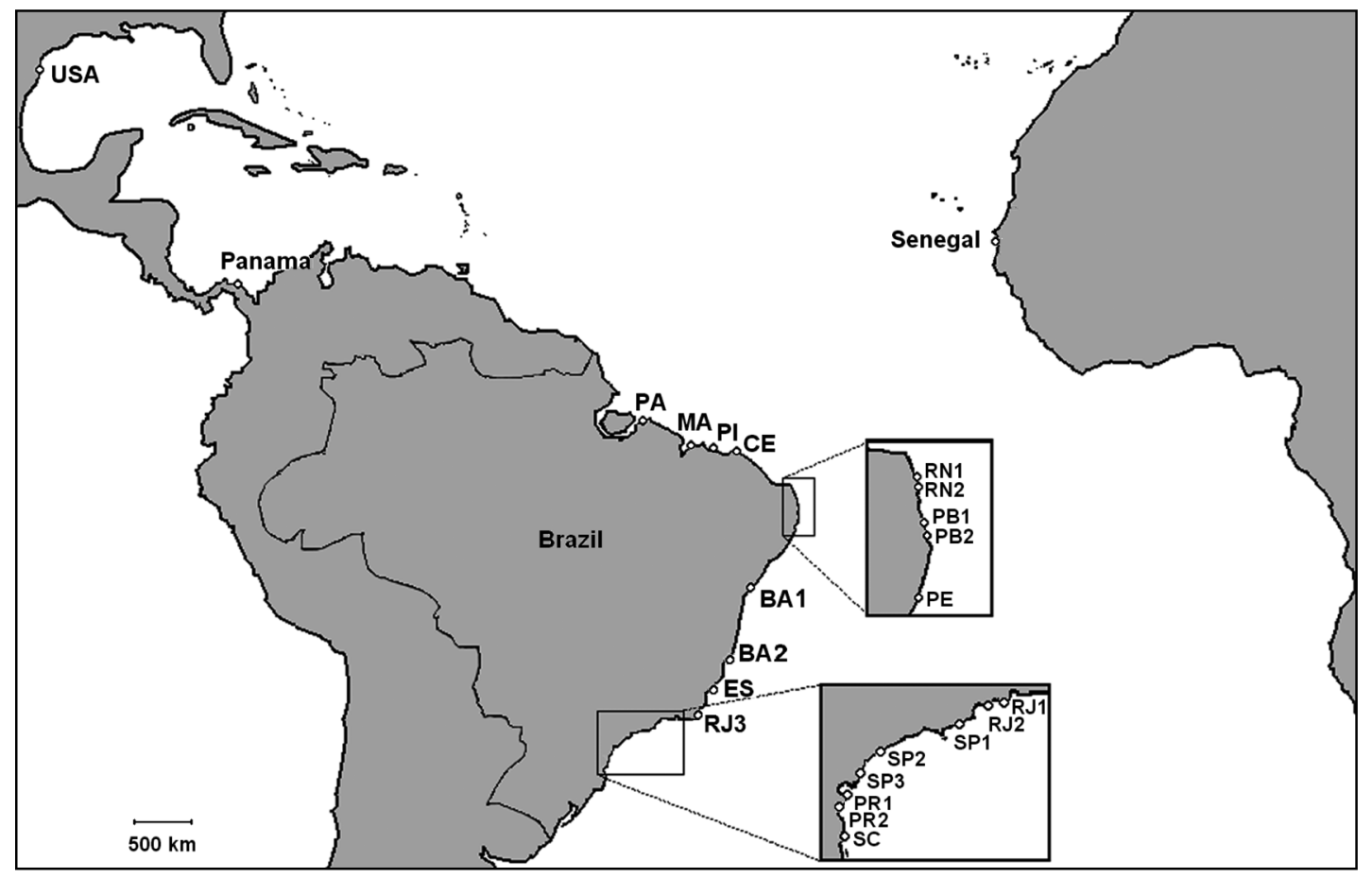

Fig. 1. Crassostrea spp. and Ostrea sp. Collection sites for specimens 


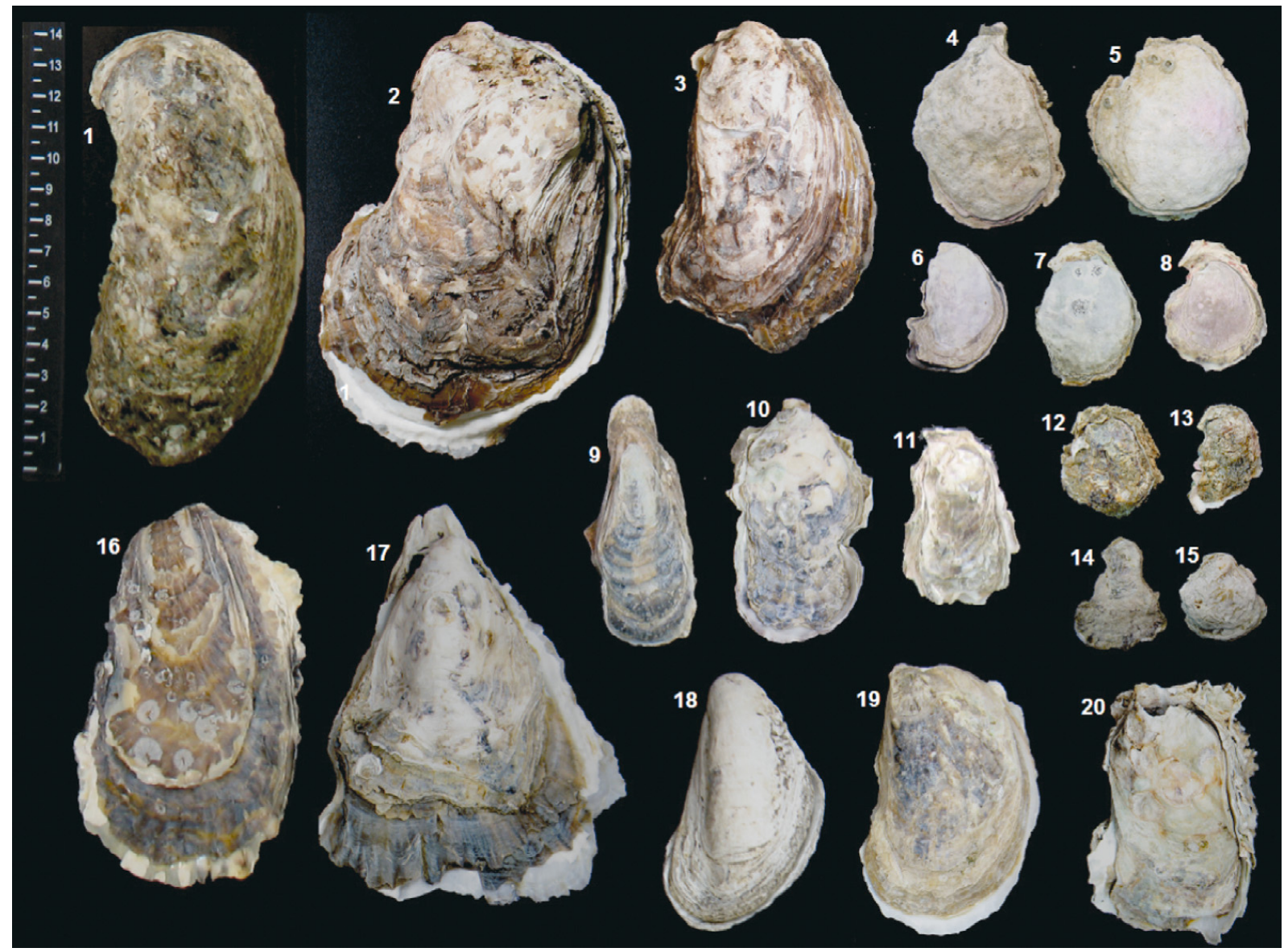

Fig. 2. Crassostrea spp. and Ostrea sp. Shells from Western Atlantic populations. C. brasiliana (Brazil): 1 (SC); 2,17 (PR1); 3 (PR2); 9, 18 (PE); 11 (PA); C. rhizophorae (Brazil): 4, 5 (RJ1); 6, 8 (RN2); 7 (SP1); 10, 20 (PR1); C. virginica (USA): 19 (Gulf of Mexico); C. gigas (Brazil): 16 (SC); Ostrea sp. (Brazil): 12, 13 (RJ1); 14, 15 (SP1). Unit scale: cm

Table 2. Enzymes studied (and abbreviations), Enzyme Commission numbers (EC), and buffer systems analyzed. TEM: $0.10 \mathrm{M}$ Tris, 0.01 M EDTA, $0.10 \mathrm{M}$ maleate, $\mathrm{pH} 7.4$; TC8: $0.25 \mathrm{M}$ Tris, $0.06 \mathrm{M}$ citrate, $\mathrm{pH}$ 8.0; LI: $0.005 \mathrm{M}$ citrate, $0.03 \mathrm{M}$ Tris (gel), $0.06 \mathrm{M} \mathrm{LiOH}, 0.30 \mathrm{M}$ borate (buffer tank), pH 8.5/8.1 (Manchenko 1994)

\begin{tabular}{|lccc|}
\hline Enzymes & Abbrev & EC & Buffers \\
\hline Adenylate kinase & AK & 2.7 .4 .3 & TEM \\
Catalase & CAT & 1.11 .1 .6 & TC8 \\
Phosphoglucomutase & PGM & 2.7 .5 .1 & TC8 \\
Phosphogluconate dehydrogenase & PGD & 1.1 .4 .4 & TEM \\
Phosphoglucose isomerase & PGI & 5.3 .1 .9 & TC8 \\
Glutamate oxaloacetate transaminase & GOT & 2.6 .1 .1 & LI \\
Isocitrate dehydrogenase & IDH & 1.1 .1 .42 & TEM \\
Leucine amino peptidase & LAP & 3.4 .1 .1 & LI \\
Malate dehydrogenase & MDH & 1.1 .1 .37 & TC8 \\
Mannose phosphate isomerase & MPI & 5.3 .1 .8 & TC8 \\
Proline-phenylalanine dipeptidase & PEP-A & 3.4 .13 .18 & TC8 \\
\hline
\end{tabular}

tides, $500 \mathrm{nM}$ of each primer, and $1.5 \mathrm{mM} \mathrm{MgCl}_{2}$ in $20 \mu \mathrm{l}$ of $1 \times$ PCR buffer (GE Life Sciences). Amplifications were performed in a mini-cycler (Sprint) programmed to begin with a denaturing step of $3 \mathrm{~min}$ at $95^{\circ} \mathrm{C}$, which was followed by 30 cycles consisting of the following steps: $94^{\circ} \mathrm{C}$ for $1 \mathrm{~min}$, $52^{\circ} \mathrm{C}$ for $1 \mathrm{~min}$, and $72^{\circ} \mathrm{C}$ for $1 \mathrm{~min}$, and a final extension step at $72^{\circ} \mathrm{C}$ for $5 \mathrm{~min}$. Negative controls, involving templatefree reactions, were included in all PCR amplifications. The primers used for the amplification of each specific genomic region were (1) 16SAR (5'-CGCCTG TTTATCAAAA ACA T-3') and 16SBR (5'-CCG GTC TGAACTCAG ATC ACG T-3') (Palumbi 1996) for the amplification of a $560 \mathrm{bp}$ fragment of the mitochondrial large ribosomal subunit (16S); (2) PH19 (5'-CAT CGA CAC TT(T/C)GAA CGC A-3') and ITS2 (5'AAT CCT GGTTAG TTT CTT TTC CTC CGC T-3') (Dixon et al. 1995) for the amplification of about 650 bp of the ITS-2; (3) LCO (5'GGT CAA CAA ATC ATA AAG ATA TTG G-3') and HCO (5' -TAA ACT TCA GGGTGA CCA AAAAAT CA$3^{\prime}$ ) (Folmer et al. 1994) for the amplification of a $700 \mathrm{bp}$ fragment of the COI mitochondrial gene; and (4) 
COIbrF (5'-GGG TTT TGAGCA GTT TTA GCCGGG-3') and COIbrR (5'-GGT CAT CCA GAA GTGTAC GTC C-3'), developed in this work, for the C. brasilianaspecific amplification of a $661 \mathrm{bp}$ fragment of COI (annealing temperature of $60^{\circ} \mathrm{C}$ ).

DNA sequencing was carried out as previously described (Gusmão et al. 2006). The purification of PCR products was performed with a GFX ${ }^{\mathrm{TM}}$ PCR DNA and Gel Band Purification Kit (GE Life Sciences) according to the manufacturer's instructions. We directly sequenced 47 ITS-2, 167 COI, and 24 16S DNA fragments from Crassostrea species originating in 24 populations. Sequences were deposited in GenBank (accession numbers FJ544267-FJ544312, FJ717606-FJ717651). Additionally, Crassostrea sequences from GenBank were included in our phylogenetic analyses (accession numbers EU007484, EU007485, EU007509, EU007511, Reece et al. 2008; NC_007175, Milbury \& Gaffney 2005; AJ312937, Lapègue et al. 2002; DQ839413, DQ839414, DQ839415, Pie et al. 2006). Sequences were aligned using the Clustal X multiple alignment program version 1.83 (Thompson et al. 1997), and alignments were confirmed by visual inspection.

DNA sequence analysis. Phylogenetic analyses were conducted using MEGA 4.0 (Tamura et al. 2007) and PAUP 4.0 (Swofford 1998) programs. Pairwise Kimura 2-parameter distances (K2P; Kimura 1980) were used to build neighbor-joining trees (Saitou \& Nei 1987). The MODELTEST 3.06 program (Posada \& Crandall 1998) was used to evaluate the most appropriate model of DNA substitution for maximum-likelihood analyses (Felsenstein 1981) of the data set. The best-fit models, which were chosen after comparisons between likelihood scores from different DNA substitution models, were the HKY model $(\mathrm{HKY}+\mathrm{G}$ : $\mathrm{A}=0.2233 ; \mathrm{C}=0.1764$; $\mathrm{G}=0.1993 ; \mathrm{T}=0.4010$; gamma $=0.1600$ ) for the COI analyses, and the K80 model (K80+G: $\mathrm{A}=0.2233 ; \mathrm{C}=$ $0.1764 ; \mathrm{G}=0.1993 ; \mathrm{T}=0.4010 ;$ gamma $=0.7191$ ) for the ITS-2 analyses. Starting tree(s) were obtained via neighbor-joining, from which a heuristic search was employed using the branch-swapping algorithm (TBR, tree-bisection-reconnection). Branch support was assessed by bootstrapping the original data set using 1000 replicates.

Divergence times, population subdivision, isolation by distance and historical demography. Allozyme genotype frequencies were used to estimate allele frequencies, level of genetic variation (heterozygosity, $H)$, fits to Hardy-Weinberg equilibrium $\left(F_{\mathrm{IS}}\right.$ W Wright $1978)$, inbreeding indices ( $F_{\mathrm{ST}}$ Wright 1978$)$, and pairwise unbiased genetic distances ( $D_{\mathrm{Nei}}$ Nei 1978$)$ using the programs BIOSYS-1 version 1.7 (Swofford \& Selander 1981) and GENETIX version 4.05 (Belkhir et al. 2002). The significance of $F_{\mathrm{IS}}\left(H_{0}: F_{\mathrm{IS}}=0\right)$ was estimated using a $\chi^{2}$ test (Waples 1987). Divergence times were estimated from allozyme data using the relationship $t=5 D_{\mathrm{Nei}} \times 10^{6}$ (Nei 1987).

Spatial analysis of molecular variance (SAMOVA; Dupanloup et al. 2002) was conducted with both allozyme and COI markers to determine hierarchical genetic structures. The significance of the fixation indices against the null hypothesis of panmixis was also evaluated using a Markov-Chain procedure with 10000 permutations, using the software ARLEQUIN version 3.11 (Excoffier et al. 2005). To test for nonrandom associations between genetic and geographic distances in Crassostrea rhizophorae and C. brasiliana populations, we used the web service IBDWS version 3.11 (Jensen et al. 2005, http://ibdws.sdsu.edu), testing the significance of pairwise correlations between $\Phi_{\mathrm{ST}}$ (or $F_{\mathrm{ST}}$, for allozyme data) and geographic distances (in $\mathrm{km}$ ) between all populations, through a Mantel test (10000 permutations). Geographic coordinates and distances between sampling sites, measured as the shortest spherical distance by sea, were obtained using Google Earth.

Haplotype $(h)$ and nucleotide $(\pi)$ diversity estimates, and 2 tests of neutrality, Tajima's $D$ (Tajima 1989) and Fu's $F_{\mathrm{S}}$ (Fu 1997), were obtained from ARLEQUIN. For the COI data, we constructed a haplotype network using the statistical parsimony procedure of Templeton et al. (1992) implemented in the TCS version 1.21 program (Clement et al. 2000). The time of divergence between species was estimated, for mitochondrial sequences, using an evolutionary rate of $1.21 \%$ sequence divergence (K2P) per million years for COI (Marko 2002).

We used mismatch distribution analysis (Rogers \& Harpending 1992), in the ARLEQUIN software, to test for historical population expansion events within oyster populations. If the sudden expansion model was not rejected, then the parameter tau $(\tau)$ was converted to time since expansion $(t=\tau / 2 \mu)$ in years before present (for $665 \mathrm{bp}, \mu=8.05 \times 10^{-6}$ substitutions per locus per year, assuming a $1 \mathrm{yr}$ generation time and a $1.21 \%$ substitution rate; Marko 2002).

We used the coalescent-based program MDIV (Nielsen \& Wakeley 2001), on CBSU Web Computing Resources (http://cbsuapps.tc.cornell.edu/mdiv.aspx), to estimate the maximum likelihood values of theta $\left(\theta=2 N_{\text {ef }} \mu\right)$, scaled migration rate $\left(M=N_{\text {ef }} m\right)$, scaled time of divergence $\left(T=t_{1} / N_{\mathrm{ef}}\right)$, and time to most recent common ancestor $\left(\mathrm{TMRCA}=t_{2} / N_{\mathrm{ef}}\right)\left(N_{\mathrm{ef}}=\right.$ effective female population size, $m=$ migration rate, $t_{1}=$ population divergence time, $t_{2}=$ gene coalescence time, and $\mu=$ mutation rate). The coalescentscaled parameter $T$ was converted to $T_{\text {div }}$ (time in years since 2 populations diverged) according to the formula: $T_{\text {div }}=T \theta /(2 \mu)$. For each pairwise comparison, a minimum of 3 chains were run using the finite 
sites model (HKY, Hasegawa et al. 1985), with a 2000000 generation Markov chain Monte Carlo (MCMC) for each simulation and a 500000 generation burn-in time, with different random seeds (set $T_{\max }$ and $M_{\max }$ to 10 ). Standard coalescent models may not be applicable to species with extremely high fecundities (Eldon \& Wakeley 2006) and high variance in the cross-generation contribution to the gene pool (the sweepstakes hypothesis; Hedgecock 1994, Hedgecock et al. 2007), like those observed in oysters. However, estimates of effective population size through different approaches can give results that are fairly well correlated even under extreme fluctuations in reproductive effort and overlapping generations (Cenik \& Wakeley 2010).

\section{RESULTS}

\section{Allozymes}

We analyzed 422 individuals from 21 Western Atlantic Crassostrea and Ostrea populations with 15 allozyme loci. Allele frequency estimates are presented in Table 3.

Heterozygosity levels were high, as is often observed in oysters (Hedgecock \& Okazaki 1984, Ignacio et al. 2000), and no significant deviations from Hardy-Weinberg expectations were found at the species level (Crassostrea brasiliana/C. paraibanensis: $F_{\mathrm{IS}}=-0.07$, $\chi^{2}=1.08, \mathrm{df}=2.52, \mathrm{p}>0.70 ; C$. rhizophorae: $F_{\mathrm{IS}}=0.06$, $\chi^{2}=1.93, \mathrm{df}=5.69, \mathrm{p}>0.80 ; C$. virginica: $F_{\mathrm{IS}}=0.07, \chi^{2}=$

Table 3. Crassostrea spp. and Ostrea sp. Allele frequencies and sample sizes (N) at 15 allozyme loci in 21 populations of Crassostrea and Ostrea species. C.p.: C. paraibanensis; C.v.: C. virginica; C.g.: C. gigas

\begin{tabular}{|c|c|c|c|c|c|c|c|c|c|c|c|c|c|c|c|c|c|c|c|c|c|}
\hline Locus & \multicolumn{9}{|c|}{ C. rhizophorae } & PR2 & $\mathrm{PA}$ & $\begin{array}{l}C . \\
\text { PB1 }\end{array}$ & $\begin{array}{l}\text { bras } \\
\mathrm{PE}\end{array}$ & $\begin{array}{r}\text { silian } \\
\text { BA1 }\end{array}$ & SP2 & $\overline{\mathrm{PR} 1}$ & $\begin{array}{l}\text { C.p. } \\
\text { PB1 }\end{array}$ & $\begin{array}{l}\text { C.V. } \\
\text { USA }\end{array}$ & $\begin{array}{l}\text { C.g. } \\
\text { SC }\end{array}$ & \multicolumn{2}{|c|}{$\begin{array}{l}\text { Ostrea sp. } \\
\text { RJ1 SP1 }\end{array}$} \\
\hline $\begin{array}{l}\boldsymbol{A} \boldsymbol{k} \\
(\mathrm{N})\end{array}$ & (10) & (15) & (20) & (10) & (23) & (24) & (22) & (10) & (19) & (32) & (12) & $(7)$ & (23) & (20) & (4) & (34) & (21) & (6) & (29) & (12) & (10) \\
\hline A & 0.15 & - & - & - & - & 0.04 & 0.02 & - & 0.13 & 0.22 & - & - & - & - & - & - & - & - & - & - & - \\
\hline B & 0.85 & 1.00 & 1.00 & 1.00 & 1.00 & 0.96 & 0.98 & 1.00 & 0.87 & 0.78 & - & - & - & - & - & - & - & - & - & - & - \\
\hline $\mathrm{C}$ & - & - & - & - & - & - & - & - & - & - & 1.00 & 1.00 & 1.00 & 1.00 & 1.00 & 1.00 & 1.00 & 1.00 & 0.67 & - & - \\
\hline D & - & - & - & - & - & - & - & - & - & - & - & - & - & - & - & - & - & - & 0.21 & 0.83 & 0.90 \\
\hline $\mathrm{E}$ & - & - & - & - & - & - & - & - & - & - & - & - & - & - & - & - & - & - & 0.12 & 0.17 & 0.10 \\
\hline $\begin{array}{l}\text { Cat } \\
\text { (N) }\end{array}$ & (13) & (15) & (16) & (10) & (12) & (20) & (18) & (4) & (19) & (32) & (12) & $(7)$ & (24) & (20) & (4) & (30) & (21) & (6) & (7) & (8) & (8) \\
\hline A & - & - & - & - & (12) & - & (10) & - & - & - & - & 0.07 & - & - & - & 0.03 & - & - & - & - & - \\
\hline B & - & - & - & - & - & - & - & - & 0.03 & - & 0.96 & 0.93 & 1.00 & 1.00 & 1.00 & 0.97 & 0.98 & - & - & 0.06 & - \\
\hline C & - & - & - & - & - & - & - & 0.12 & 0.13 & 0.20 & 0.04 & - & - & - & - & - & 0.02 & - & - & 0.94 & 1.00 \\
\hline D & 0.15 & 0.67 & 0.66 & 0.65 & 0.67 & 0.53 & 0.53 & 0.50 & 0.74 & 0.64 & - & - & - & - & - & - & - & - & 0.93 & - & - \\
\hline E & 0.85 & 0.33 & 0.34 & 0.35 & 0.33 & 0.42 & 0.47 & 0.38 & 0.10 & 0.16 & - & - & - & - & - & - & - & 1.00 & 0.07 & - & - \\
\hline F & - & - & - & - & - & 0.05 & - & - & - & - & - & - & - & - & - & - & - & - & - & - & - \\
\hline $\begin{array}{l}\text { Got } \\
(\mathrm{N})\end{array}$ & (14) & (15) & (20) & (10) & (23) & (27) & (22) & (10) & (19) & (32) & (12) & $(7)$ & (24) & (20) & (4) & (34) & (21) & (6) & (31) & (12) & (10) \\
\hline A & - & - & - & - & - & - & (2L) & - & (10) & - & 1.00 & 1.00 & 1.00 & 1.00 & 1.00 & 0.96 & 1.00 & (D) & - & - & - \\
\hline B & - & - & - & - & - & - & - & - & - & - & - & - & - & - & - & 0.04 & - & - & - & 1.00 & 1.00 \\
\hline C & 1.00 & 1.00 & 1.00 & 1.00 & 1.00 & 1.00 & 1.00 & 1.00 & 1.00 & 1.00 & - & - & - & - & - & - & - & 1.00 & 1.00 & - & - \\
\hline Idh-1 & & & & & & & & & & & & & & & & & & & & & \\
\hline$(\mathrm{N})$ & (14) & (15) & (20) & (10) & (23) & (27) & (22) & (10) & (19) & (32) & (12) & $(7)$ & (24) & $(20)$ & (4) & (34) & (21) & (6) & (29) & (12) & (10) \\
\hline A & - & - & - & - & - & - & - & - & - & - & 0.96 & 1.00 & 1.00 & 1.00 & 1.00 & 0.99 & 0.98 & - & - & - & - \\
\hline B & - & - & - & - & 0.02 & - & 0.02 & - & 0.03 & - & 0.04 & - & - & - & - & 0.02 & 0.02 & - & - & - & - \\
\hline C & 0.86 & 1.00 & 1.00 & 0.95 & 0.96 & 0.91 & 0.96 & 1.00 & 0.89 & 0.94 & - & - & - & - & - & - & - & - & 0.02 & - & - \\
\hline D & - & - & - & - & - & - & 0.02 & - & - & - & - & - & - & - & - & - & - & - & 0.74 & 1.00 & 1.00 \\
\hline E & 0.14 & - & - & 0.05 & 0.02 & 0.09 & - & - & 0.08 & 0.06 & - & - & - & - & - & - & - & 1.00 & - & - & - \\
\hline F & - & - & - & - & - & - & - & - & - & - & - & - & - & - & - & - & - & - & 0.24 & - & - \\
\hline Idh-2 & & & & & & & & & & & & & & & & & & & & & \\
\hline$(\mathrm{N})$ & (14) & (15) & (20) & (10) & (23) & (27) & (22) & (10) & (19) & (32) & (12) & $(7)$ & (24) & (20) & (4) & (34) & (21) & (6) & (29) & (12) & (10) \\
\hline A & - & - & - & - & 0.02 & - & - & - & - & 0.02 & - & - & - & - & - & - & - & - & - & - & - \\
\hline B & 1.00 & 1.00 & 1.00 & 1.00 & 0.96 & 0.98 & 1.00 & 1.00 & 1.00 & 0.98 & - & - & - & - & - & - & - & - & - & - & 0.10 \\
\hline C & - & - & - & - & 0.02 & 0.02 & - & - & - & - & - & - & - & - & - & - & - & - & 1.00 & 1.00 & 0.90 \\
\hline D & - & - & - & - & - & - & - & - & - & - & - & - & - & - & - & - & - & 1.00 & - & - & - \\
\hline E & - & - & - & - & - & - & - & - & - & - & 1.00 & 1.00 & 1.00 & 1.00 & 1.00 & 1.00 & 1.00 & - & - & - & - \\
\hline Lap & & & & & & & & & & & & & & & & & & & & & \\
\hline (N) & (14) & (15) & $(20)$ & (9) & (23) & (27) & (22) & (10) & (19) & (32) & (12) & (7) & (24) & (20) & (4) & (34) & (21) & (6) & (29) & (12) & (10) \\
\hline A & - & - & - & - & - & - & - & - & 0.05 & 0.02 & - & - & - & - & - & - & - & - & - & 1.00 & 1.00 \\
\hline B & 0.11 & 0.03 & 0.15 & - & - & 0.02 & - & - & 0.29 & 0.22 & - & 0.07 & - & - & - & 0.04 & 0.02 & - & 1.00 & - & - \\
\hline C & 0.89 & 0.97 & 0.85 & 1.00 & 0.98 & 0.98 & 0.89 & 1.00 & 0.66 & 0.75 & 0.88 & 0.79 & 1.00 & 1.00 & 1.00 & 0.93 & 0.96 & 1.00 & - & - & - \\
\hline D & - & - & - & - & 0.02 & - & 0.11 & - & - & 0.01 & 0.12 & 0.07 & - & - & - & 0.03 & 0.02 & - & - & - & - \\
\hline E & - & - & - & - & - & - & - & - & - & - & - & 0.07 & - & - & - & - & - & - & - & - & - \\
\hline
\end{tabular}


Table 3 (continued)

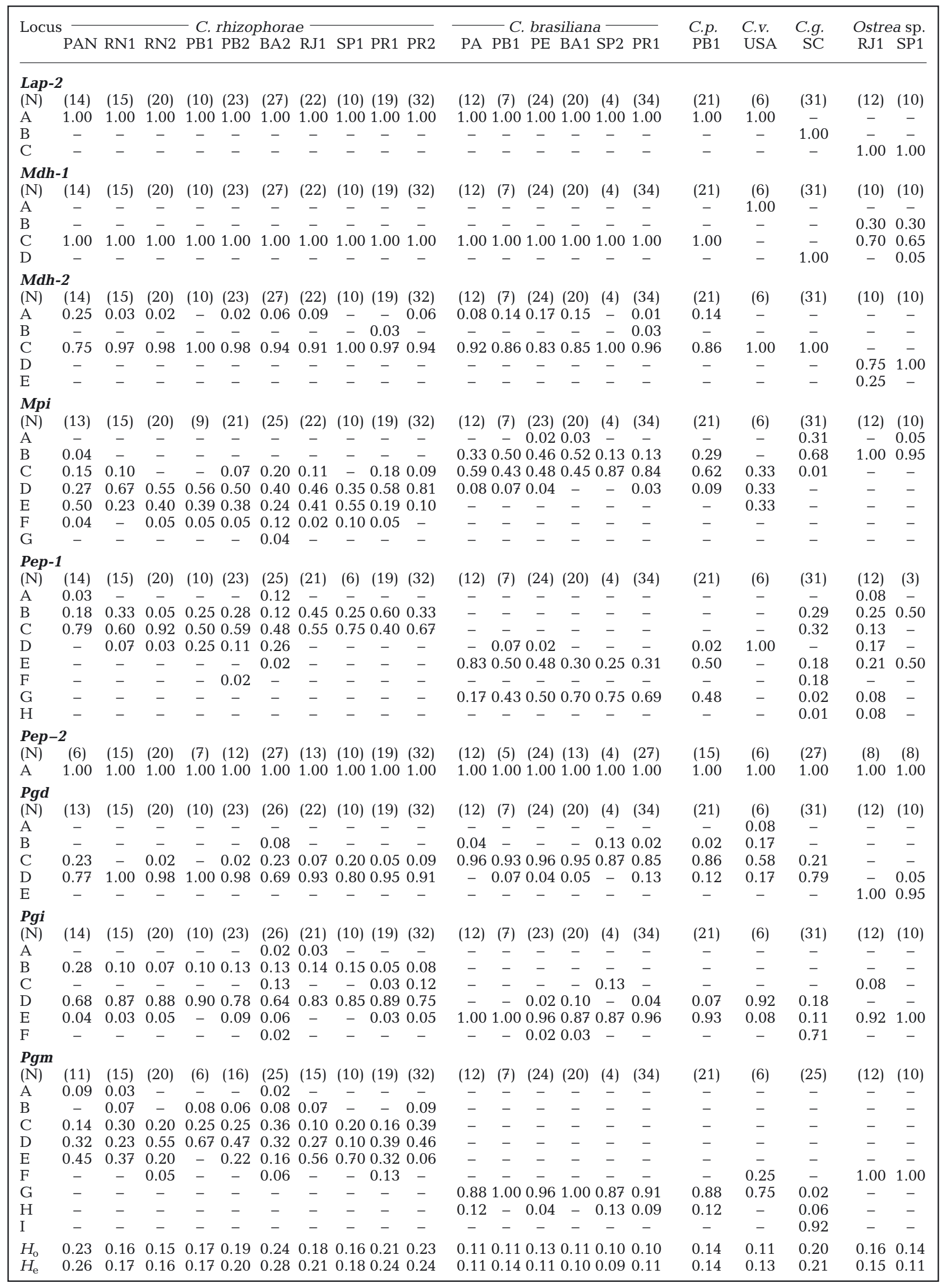


0.05, df $=2.41, \mathrm{p}>0.90 ;$ C. gigas: $F_{\mathrm{IS}}=0.04, \chi^{2}=0.12$, $\mathrm{df}=3.32, \mathrm{p}>0.90$; Ostrea sp.: $F_{\mathrm{IS}}=-0.22, \chi^{2}=0.47, \mathrm{df}=$ $0.32, \mathrm{p}>0.40$ ).

We found 3 diagnostic loci that distinguished Crassostrea rhizophorae from C. virginica, 5 that distinguished C. rhizophorae from C. brasiliana, 6 that distinguished $C$. brasiliana from $C$. virginica, and 6 that distinguished $C$. virginica from $C$. gigas (Table 3). Although specimens of $C$. virginica and $C$. brasiliana are morphologically very similar, the former seems to be genetically more closely related to $C$. rhizophorae (Fig. 3). C. brasiliana and C. paraibanensis were genetically indistinguishable $\left(D_{\mathrm{Nei}}=0\right)$.

Intraspecific genetic distances were short among Brazilian populations of Crassostrea brasiliana $\left(D_{\mathrm{Nei}}=\right.$ 0 to 0.03$)$ and of $C$. rhizophorae $\left(D_{\mathrm{Nei}}=0\right.$ to 0.08$)$ (Fig. 3). Despite the large geographic distances involved (up to $9000 \mathrm{~km}$ ), the genetic distances separating $C$. rhizophorae populations from Panama and Brazil were also small $\left(D_{\mathrm{Nei}}=0.02\right.$ to 0.08$)$.

Populations of both species were found to be genetically structured in the Western Atlantic. Eight genetically different groups could be detected in Crassostrea rhizophorae: (1) Panama; (2) RN1; (3) RN2; (4) PB1, PB2; (5) BA2; (6) RJ1, SP1; (7) PR1; and (8) PR2 (SAMOVA: $\left.F_{\mathrm{CT}}=0.09 ; \mathrm{p}<0.001\right)$. Three genetic stocks were observed in C. brasiliana: (1) $\mathrm{PA}_{i}$ (2) PB1, PE, BA1; and (3) SP2, PR1 (SAMOVA: $F_{\mathrm{CT}}=0.08, \mathrm{p}<0.01$ ).
Mantel tests for both species showed significant isolation by distance (IBD) relationships (C. rhizophorae: $\mathrm{r}=$ 0.53, $\mathrm{p}<0.05$; C. brasiliana: $\mathrm{r}=0.77, \mathrm{p}<0.01$; Fig. 4), even after excluding the very divergent Panamanian C. rhizophorae population $(\mathrm{r}=0.36, \mathrm{p}<0.05)$.

\section{DNA markers}

Analyses with the 3 DNA markers showed congruent results regarding interspecific relationships. ITS-2 intraspecific variation was low in all species (Crassostrea rhizophorae: 4 haplotypes, $h=0.271, \pi=0.001$; C. virginica: 1 haplotype; C. brasiliana/C. paraibanensis: 1 haplotype; and C. gasar: 2 haplotypes, $h=0.400$, $\pi=0.003)$. C. brasiliana, C. paraibanensis and C. gasar were genetically extremely similar $(\mathrm{K} 2 \mathrm{P}<0.008)$, whereas the other species could be readily distinguished by their ITS-2 sequences (Fig. 5).

We found 28 different COI haplotypes in the Western Atlantic populations of Crassostrea rhizophorae ( $h=0.866, \pi=0.007), 10$ haplotypes in the South American populations of $C$. brasiliana $(h=0.590, \pi=0.003)$, 3 haplotypes in the Brazilian population of C. paraibanensis ( $h=0.524, \pi=0.001$ ), and only 1 haplotype in the C. gasar population from Joal-Fadiouth (Senegal, Africa). As observed with the ITS-2 sequences, $C$. brasiliana, C. paraibanensis and C. gasar were very
Fig. 3. Crassostrea spp. and Ostrea sp. UPGMA tree based on genetic distances (Nei 1978) between Crassostrea and Ostrea populations

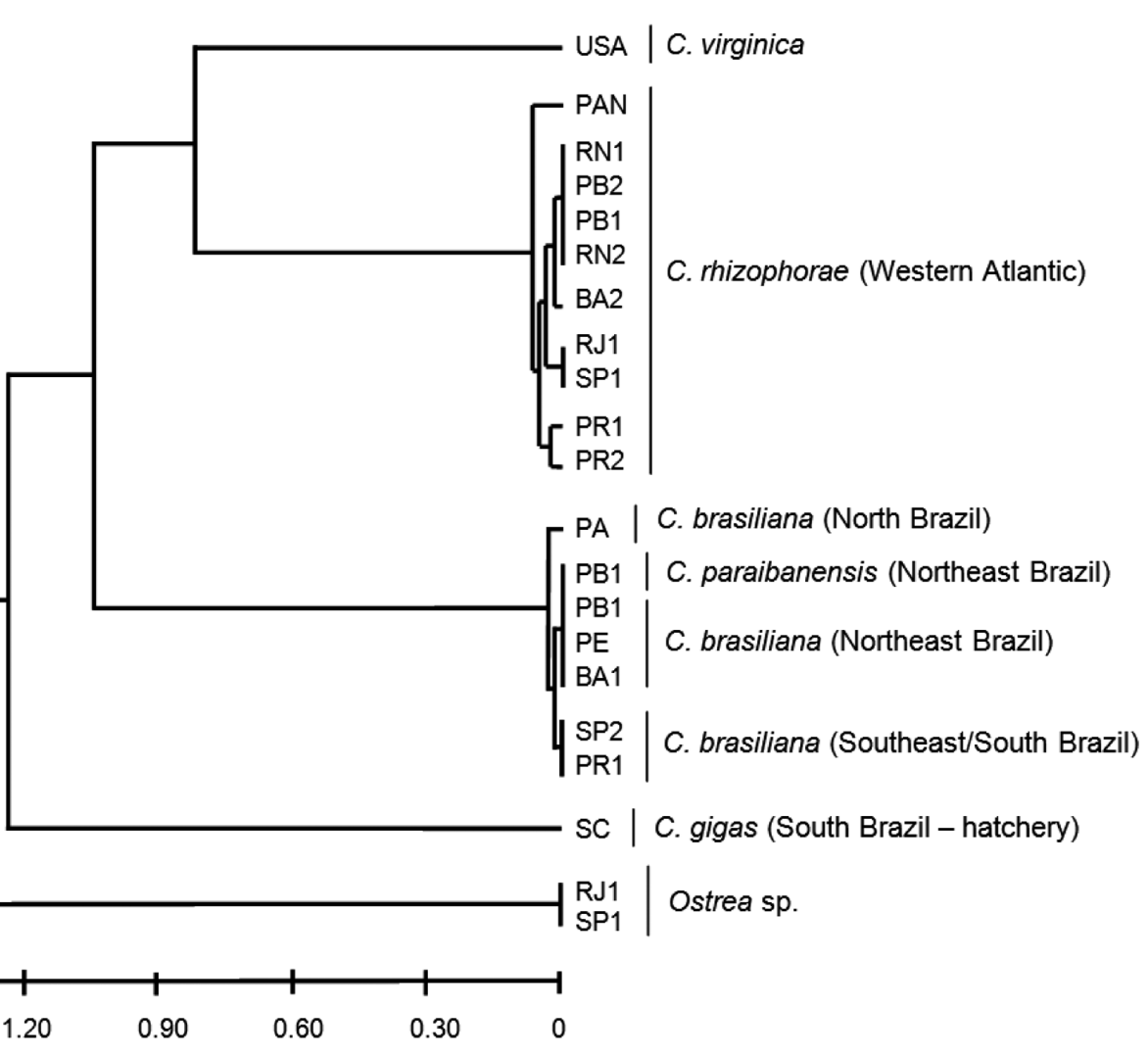


C. brasiliana - allozymes

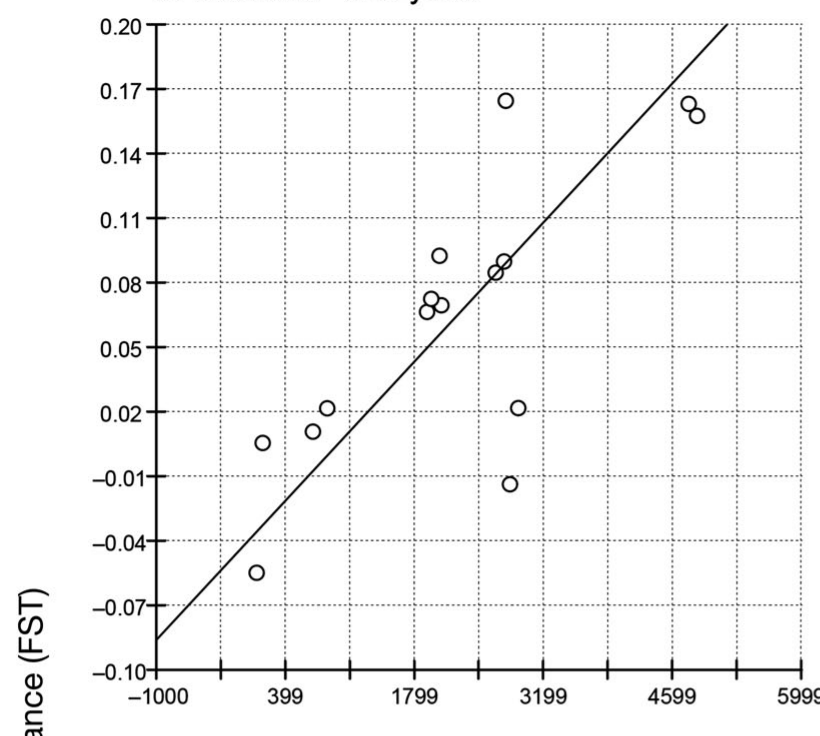

C. rhizophorae - allozymes

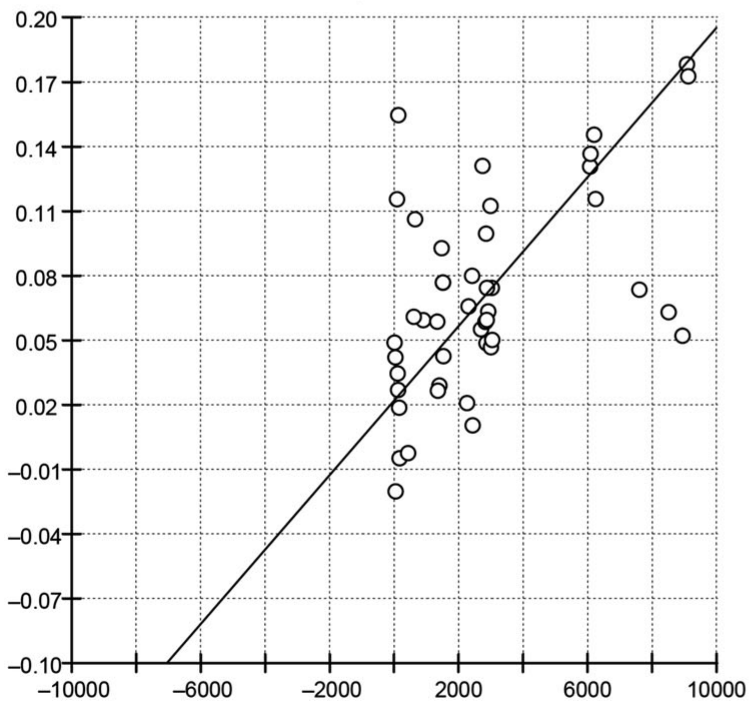

C. brasiliana - COI

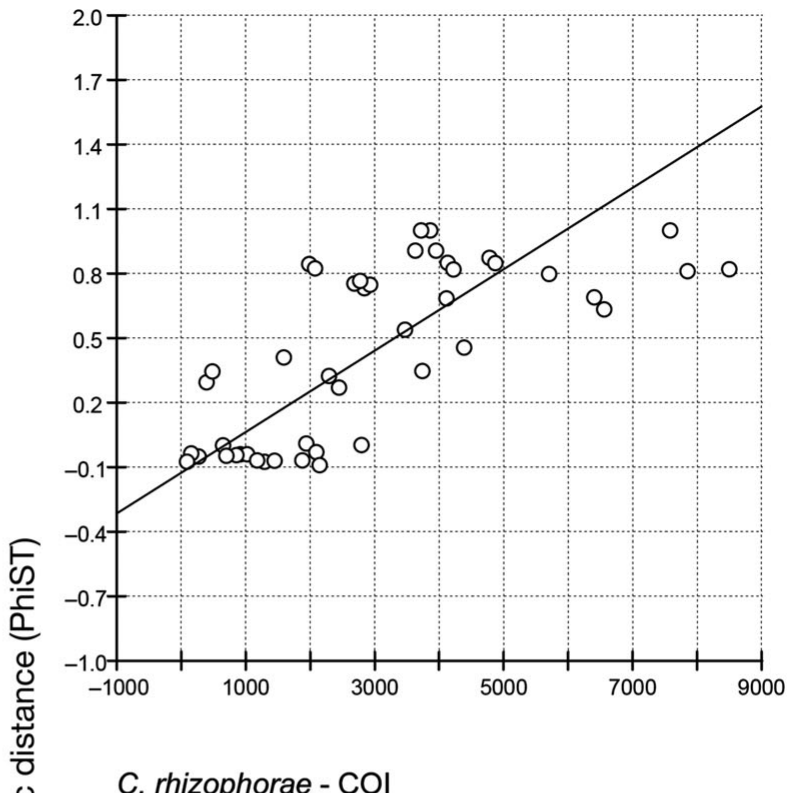

C. rhizophorae - COI

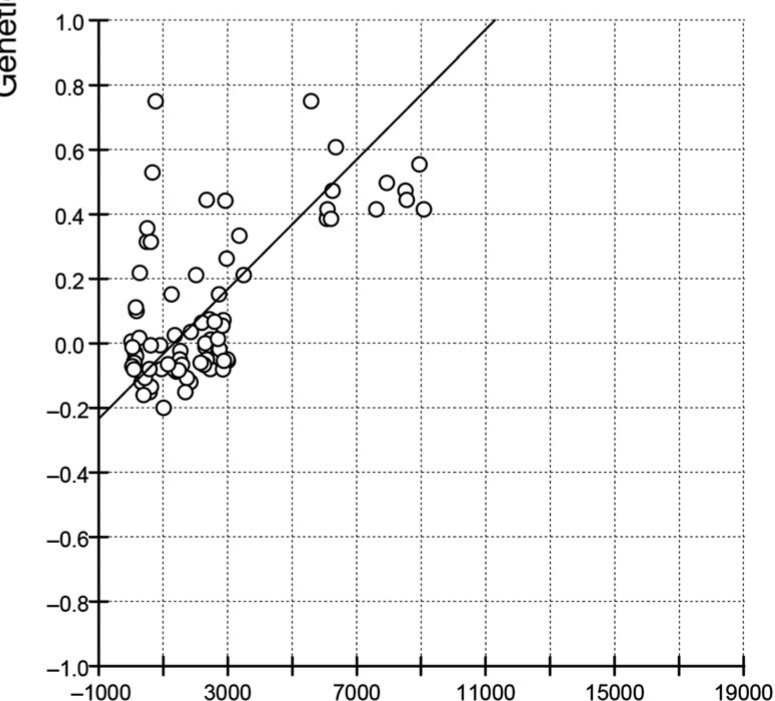

Geographic distance

Fig. 4. Crassostrea spp. Pairwise comparison between genetic (linearized $F_{\mathrm{ST}} / \Phi_{\mathrm{ST}}$ ) and geographical (linearized km) distances based on nuclear (allozymes) and mitochondrial (COI) markers

similar in their COI sequences (K2P < 0.008). Again, COI sequences clearly differentiated the other analyzed Crassostrea species (K2P varied between 0.16 and 0.27; Fig. 6). Intraspecific pairwise divergences of C. rhizophorae were low both for the Brazilian (K2P < 0.008) and the Caribbean (Panama, K2P < 0.003) populations. In contrast, a large differentiation ( $\mathrm{K} 2 \mathrm{P}=0.018$ to 0.025 ) was found between sequences from Brazilian and Panamanian specimens, which clustered in separate clades with high bootstrap support in the neighbor-joining and maximum likelihood trees (Fig. 6).
With the exception of Crassostrea brasiliana/C. paraibanensis/C. gasar, which had identical 16S sequences, the other Crassostrea species were well differentiated (Fig. 7). Interspecific sequence differentiation was 0.036 between $C$. rhizophorae and $C$. virginica and 0.118 between $C$. rhizophorae and $C$. brasiliana. No intraspecific variation was found in the $16 \mathrm{~S}$ sequences analyzed.

Populations of both Crassostrea rhizophorae and C. brasiliana were found to be genetically structured in the Western Atlantic. Two highly divergent genetic 


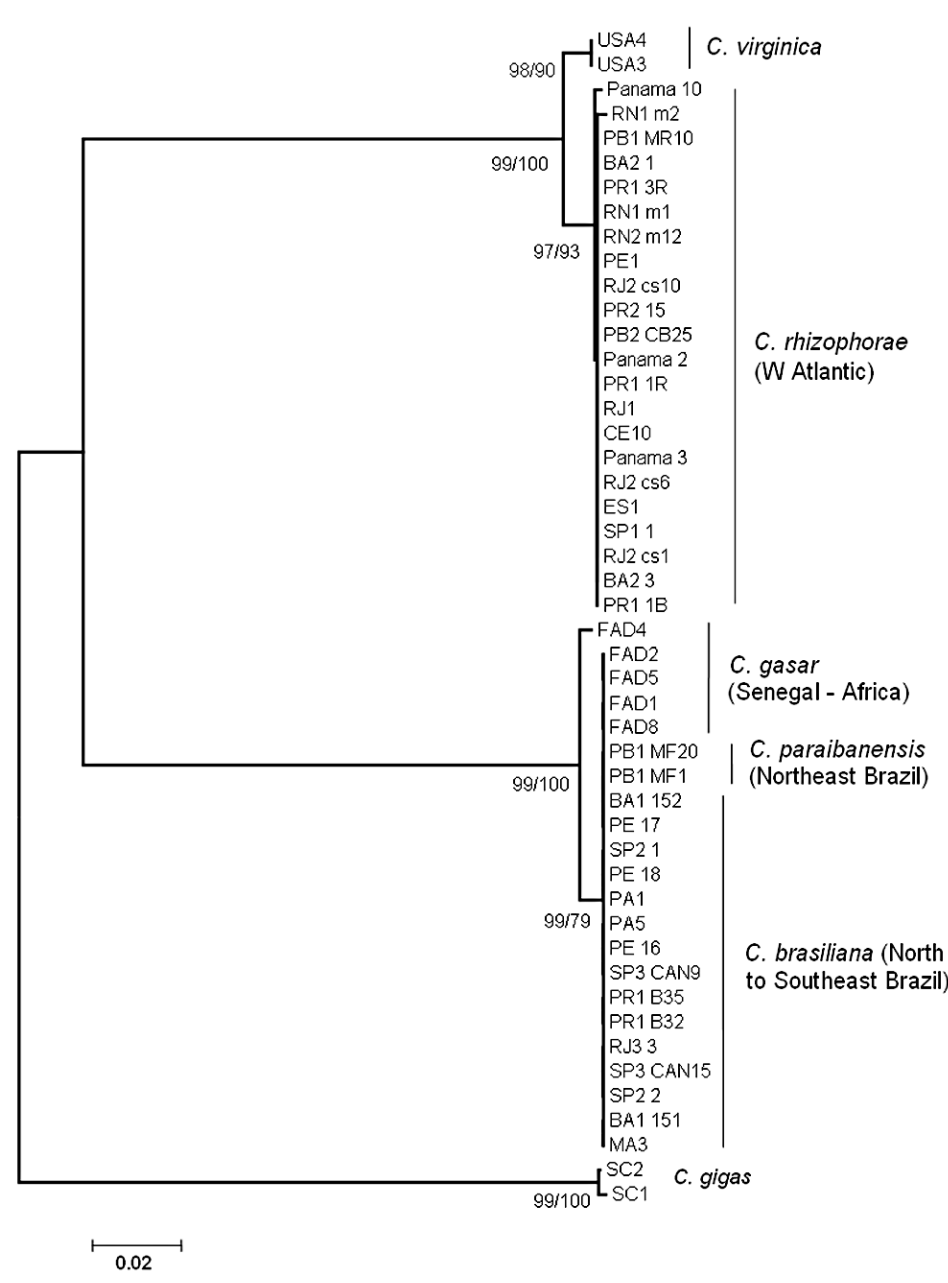

Fig. 5. Crassostrea spp. ITS-2-based (521 bp) tree. The numbers below the branches are bootstrap values (1000 replicates) for neighbor-joining and maximum likelihood trees, respectively

groups could be detected in C. rhizophorae: (1) Panama and (2) Brazil (SAMOVA COI data: $F_{\mathrm{CT}}=0.894, \mathrm{p}<$ 0.0001; Fig. 8). Excluding Panama from the analysis, 10 genetic stocks could be detected in C. rhizophorae: (1) $\mathrm{CE}_{\text {; }}$ (2) RN1; (3) RN2; (4) PB1; (5) PB2; (6) PE; (7) BA2; (8) ES, RJ2, SP1; (9) RJ1; and (10) PR1, PR2 (SAMOVA COI data: $F_{\mathrm{CT}}=0.156, \mathrm{p}<0.001$ ). These population groupings are similar to those observed in the allozyme analyses. Three genetic stocks were observed in C. brasiliana: (1) PA, PB1, PE, BA1; (2) RJ3; and (3) SP2, PR1, PR2 (SAMOVA COI data: $F_{\mathrm{CT}}=0.724$, $\mathrm{p}<0.001$; Fig. 8). The C. gasar population from JoalFadiouth formed a fourth group when included in the analyses (SAMOVA COI data: C. brasiliana/C. gasar: $F_{\mathrm{CT}}=0.738, \mathrm{p}<0.001$; Fig. 8). As seen with allozymes, a significant correlation between geographic and genetic distances was observed in the COI analyses for $C$. brasiliana (Mantel test: $r=0.713, p<0.0001$; Fig. 4), whereas in C. rhizophorae the correlation was only sig- nificant when including the highly differentiated Panamanian population (Fig. 4).

A significant departure from neutrality was observed for the Crassostrea rhizophorae populations from Panama (Tajima's $D=-1.43, \mathrm{p}=$ 0.03; Fu's $\left.F_{\mathrm{S}}=-26.30, \mathrm{p}=0\right)$ and Brazil $(D=$ $-2.35, \mathrm{p}<0.001 ; F_{\mathrm{S}}=-27.84, \mathrm{p}=0$ ), and for $C$. brasiliana from northern and northeastern $\left(D=-2.09, \mathrm{p}=0.002 ; F_{\mathrm{S}}=-6.62, \mathrm{p}=0.001\right)$ and southeastern and southern $(D=-1.67, \mathrm{p}=0.026$; $\left.F_{\mathrm{S}}=-0.60, \mathrm{p}=0.209\right)$ Brazilian populations. A unimodal distribution was observed in the mismatch analyses both for C. rhizophorae and C. brasiliana, closely matching the expected distributions under the sudden expansion model. Time estimates for population expansion were 27 thousand years ago (kya) for C. rhizophorae from Panama $(\tau=0.44)$ and 107 kya for $C$. rhizophorae from Brazil $(\tau=1.72)$. For $C$. brasiliana, estimates of time since expansion were 171 kya for the N/NE population $(\tau=2.75)$ and 186 kya for the SE/S population $(\tau=3.00)$.

\section{DISCUSSION}

\section{Synonymy of Crassostrea brasiliana, C. paraibanensis and C. gasar}

The 3 Western Atlantic Crassostrea species studied in this work, C. rhizophorae, C. brasiliana and $C$. virginica, could be readily distinguished by both nuclear (allozymes and ITS-2) and mitochondrial (COI and 16S) markers. On the other hand, C. brasiliana and the African C. gasar clustered together in all DNA analyses, which indicates that they are conspecific, as previously suggested (Verdon 2000, Lapègue et al. 2002) based on smaller data sets. Additionally, oysters found on rocks in the subtidal zone of the same shore where C. paraibanensis was described (Singarajah 1980) were genetically indistinguishable from C. brasiliana/ C. gasar. We can safely conclude, therefore, that the nominal species C. paraibanensis and $C$. brasiliana are junior synonyms of $C$. gasar, which, henceforth, will be the name used to denominate both the South American and African oysters.

Moreau (2001) used restriction fragment length polymorphism (RFLP) analyses of ITS-2 to compare African and South American oysters identified as Crassostrea gasar and reported 2 different restriction patterns, H1 and $\mathrm{H} 2$, in the African specimens, but only $\mathrm{H} 2$ in the South American specimens. Because the African populations of $C$. gasar were more polymorphic, the author suggested that oysters from South America might have originated from African oysters. 


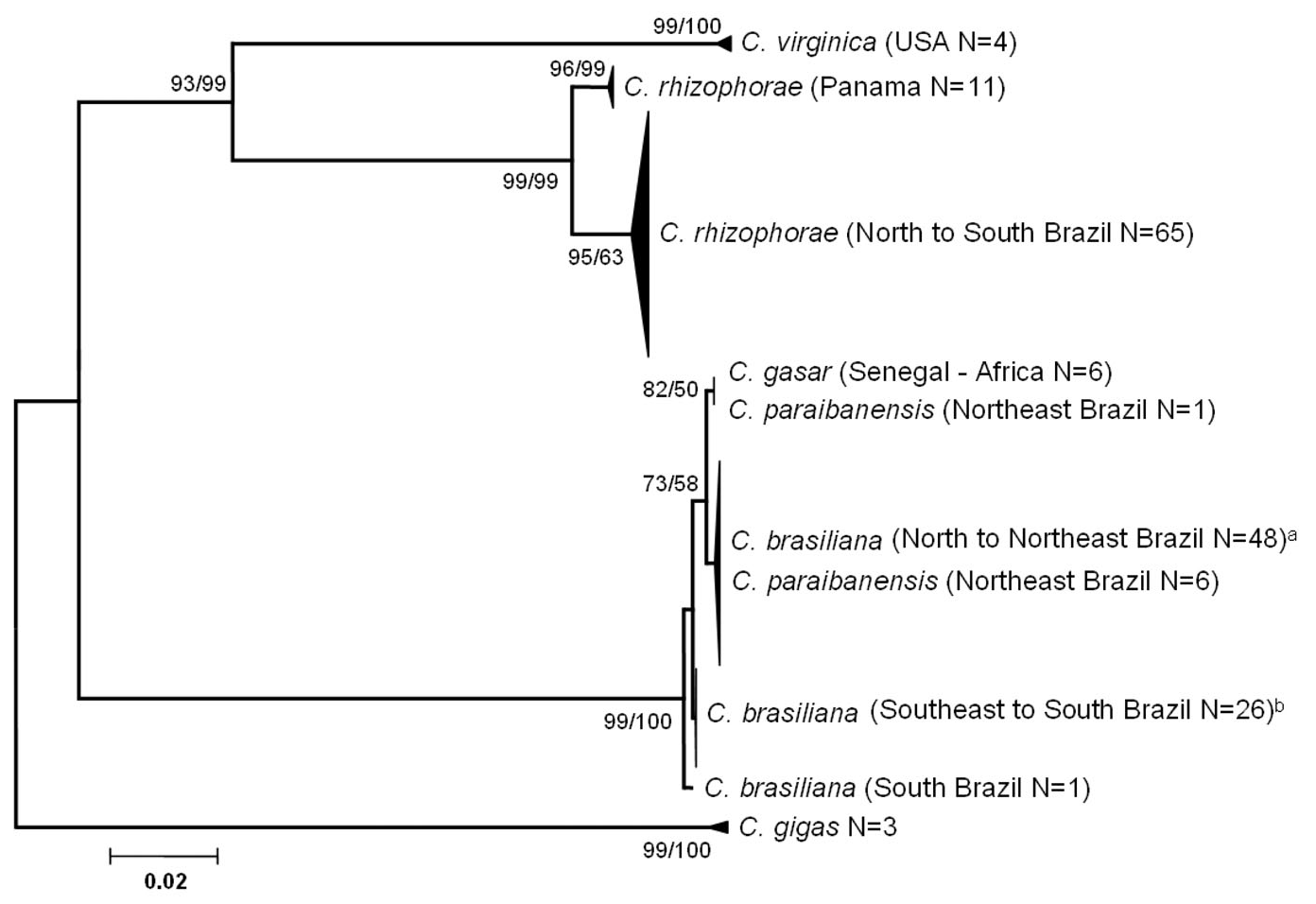

Fig. 6. Crassostrea spp. Cytochrome $c$ oxidase subunit I-based (648 bp) tree. The numbers on the branches are bootstrap values (1000 replicates) for neighbor-joining and maximum likelihood trees, respectively. ' $a$ ' and ' $b$ ' indicate the presence of haplotypes with individuals from more than one region (a: Southeast $\mathrm{N}=2$; $\mathrm{b}$ : Northeast $\mathrm{N}=4$ )

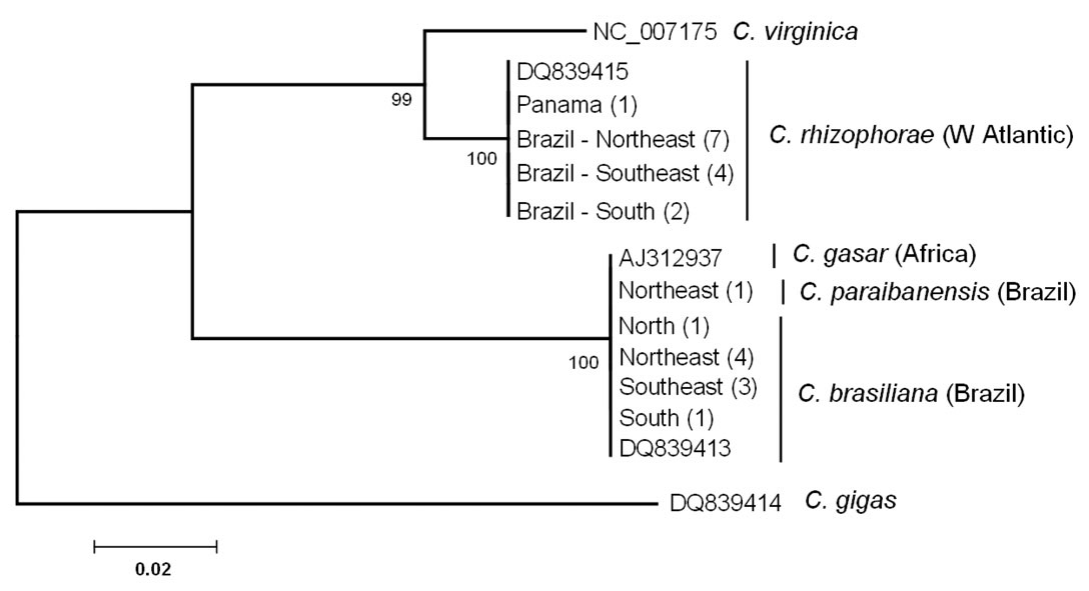

Fig. 7. Crassostrea spp. 16S-based (495 bp) neighbor-joining tree. The numbers below the branches are bootstrap values (1000 replicates). The numbers in parentheses represent the total number of individuals sequenced with each haplotype

The high similarity between populations of the same oyster species on both sides of the South Atlantic indicates a recent dispersal event. This could have been either a naturally occurring event, such as the dispersal of larvae by the equatorial current (Lapègue et al. 2002) or of adults by rafting (Ó Foighil et al. 1999). Alternatively, it might be the result of the anthro- pogenic transport of larvae in ballast water or of adults incrusting ship hulls as suggested by Lapègue et al. (2002).

The fossil records identified as Crassostrea gasar from Senegal (near Bassoul) (Demarcq \& Demarcq 1992) and as C. 'brasiliana' from Brazil (S/SE regions) (Fairbridge 1976), date from the Holocene period (4000 to $6000 \mathrm{yr}$ ago), thus refuting the anthropogenic transport hypothesis for the occurrence of $C$. gasar on both continents. In any case, the very high genetic similarity, across nuclear and mitochondrial genes, rules out vicariance as the origin of the African and South American oyster populations, since the 2 continents have been separated for over 16 million yr.

Cytochrome oxidase gene sequences from African Crassostrea gasar specimens were more similar to those from C. gasar from N/NE Brazil than to sequences from other parts of the Brazilian coast. This is compatible with colonization by natural dispersal from Africa through the westerly flowing Equatorial Current, which arrives in Brazil on its northeastern 


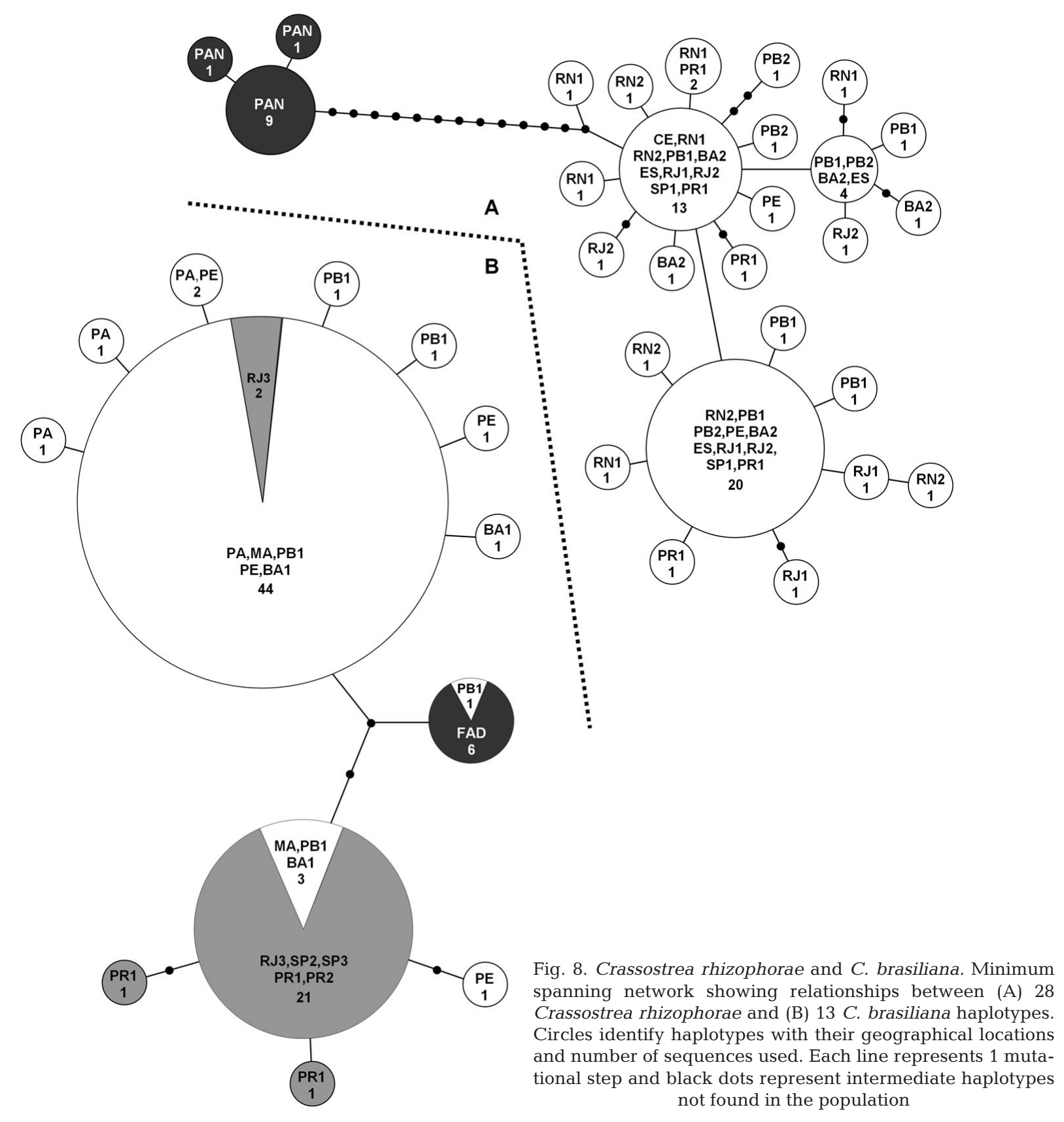

coast. The higher levels of polymorphism of RFLP ITS-2 patterns of African samples were also interpreted as evidence for an African origin of the species (Moreau 2001). Contrastingly, we found a higher nucleotide diversity in Brazilian than in African $C$. gasar, which might indicate a South American origin for the species, but which might also result from the maintenance of a larger effective population size of the species on the Brazilian coast, contradicting the conclusion of Moreau (2001) based on RFLP ITS-2 patterns.

The genetic similarity observed between Crassostrea gasar and C. 'brasiliana' is higher than that found between Pacific (C. gigas) and Portuguese (C. angulata) oysters (Batista et al. 2006). Until recently, these 2 species were considered distinct based on fossil records and geographic distribution. Nevertheless, there are strong physiological, morphological, reproductive and genetic similarities between them, which suggest they may be closely related species or even the same Pacific species (Boudry et al. 1998, Leitão et al. 2007), probably transported anthropogenically from Taiwan. 


\section{Phylogenetic relationships among Atlantic Crassostrea species and fossil records}

All phylogenetic analyses demonstrated that the morphologically highly similar species, Crassostrea rhizophorae and C. virginica, are sister species genetically very different from C. gasar. However, C. gasar still groups with the other Atlantic oysters. The small genetic distances (allozymes: $D_{\mathrm{Nei}}=0.02$ to 0.08 ) found between C. rhizophorae populations from Panama and Brazil (6000 to $9000 \mathrm{~km}$ apart) are similar to the genetic distances observed in comparisons of other marine organisms in those regions (Lazoski et al. 2001, Williams et al. 2001, Gusmão et al. 2006). This similarity provides additional support for the hypothesized close relationship of Caribbean and Brazilian faunas (Briggs 1974).

Crassostrea oysters, like other ostreids, are believed to have originated during the Late Cretaceous, like e.g. C. soleniscus (Meek, 1871) and C. cusseta Sohl \& Kauffman, 1964 (Stenzel 1971), or earlier, in the Mid Jurassic period, like C. tetoriensis Komatsu \& Chinzei, 2002 (Komatsu et al. 2002). During the Oligocene and Miocene periods, there was a great variety of oyster species, most of which had large and thick shells and inhabited littoral areas in the Western Atlantic (Kirby 2001). Some of these oysters probably gave rise to the Atlantic Crassostreini lineage after the Tethys Seaway closure (Ó Foighil \& Taylor 2000).

Fossil records from the eastern coast of the USA (from the Priaborian period, Late Eocene, 37 million years ago, Ma) show the presence of a very large oyster, Crassostrea gigantissima (Finch, 1824), which was replaced by oysters similar to $C$. virginica in the Early Miocene strata (Aquitanian period, $23 \mathrm{Ma}$; Sohl \& Kauffman 1964, Lawrence 1995, Kirby 2001). As a result, C. virginica is usually seen as a direct descendant of C. gigantissima or of an extinct common ancestor (Sohl \& Kauffman 1964, Lawrence 1995, Kirby 2000). The American fossils identified as C. virginica, both from the Miocene and from the Holocene periods, had thin shells, whereas the Pliocene and Pleistocene 'C. aff. virginica' specimens from the USA and Caribbean are thick-shelled (Kirby 2000, 2001). If this is correct, it means that $C$. virginica changed back from thin to thick shells during the Miocene-Holocene period. However, this conjecture is not consistent with the reported tendency of large and thick-shelled oysters to evolve into smaller and thinner-shelled species (Kirby 2000). This raises doubt as to the presence of C. virginica in the Miocene strata.

The divergence times estimated through allozymes and mitochondrial data indicate that Crassostrea virginica and C. rhizophorae diverged in the Pliocene period (6.8 to 3.2 Ma), after the evolutionary split in the lineages leading to $C$. gasar and the ancestor of $C$. virginica and $C$. rhizophorae, which happened between the Miocene and the early Pliocene periods (9.5 to 4.6 Ma).

Based on the morphological and ecological similarities of Crassostrea gasar and C. virginica (Sandison \& Hill 1966), it is important to consider the presence of C. gasar in the fossil record. This has not been done previously, because C. gasar was not considered a valid species in the Western Atlantic, so its morphological features (like the presence of thick and large shells) were only considered a part of the phenotypic space occupied by $C$. virginica and $C$. rhizophorae.

Pleistocene and Pliocene thick- and large-shelled oysters from the Atlantic and Caribbean (also identified as 'Crassostrea virginica' and 'C. aff. virginica'; Kirby 2000, 2001, Kirby \& Jackson 2004) can be either C. virginica or C. gasar. This casts doubt on the identification of thick-shelled fossil oyster specimens as $C$. virginica, which means that the identification of fossil oysters, at least in the USA and Caribbean, should be revised.

Fossils identified as Crassostrea virginica date from the same period as those of C. titan (Conrad, 1853) from the state of California (USA) and C. cahobasensis (Pilsbry \& Brown, 1917) from the Caribbean, which have large and thick shells (Kirby 2001) like those of C. gasar. Those shell features have been used to infer the habitat and other ecological characteristics of fossil oysters (Kirby 2000), and to aid in their classification (Sohl \& Kauffman 1964, Stenzel 1971). However, the use of shell characteristics to distinguish crassostreine genera has been criticized (Lawrence 1995). As the identification of extant oyster species based solely on their external shell features can clearly be misleading, correctly identifying and classifying fossil oysters based on those same shell characteristics is a difficult task (Lawrence 1995, Valentine et al. 2006).

\section{Geographical distribution, isolation by distance, and historical demography of Western Atlantic Crassostrea rhizophorae and C. gasar}

Crassostrea rhizophorae was found in 13 of 21 locations studied, from the Caribbean (Panama) to southern Brazil (Paraná State, $25^{\circ} 51^{\prime} \mathrm{S} ; 48^{\circ} 35^{\prime} \mathrm{W}$ ), and C. gasar was found in 12 sites along the Brazilian coast ranging from the northern (Pará State, $01^{\circ} 25^{\prime} \mathrm{S} ; 48^{\circ} 28^{\prime} \mathrm{W}$ ) to the southern (Paraná State, $25^{\circ} 51^{\prime} \mathrm{S}_{;} 48^{\circ} 35^{\prime} \mathrm{W}$ ) regions. C. rhizophorae was only found in the intertidal environments. In contrast, C. gasar, which is known to live mainly in the subtidal zone, was also found in 8 intertidal sites, and in 2 of them (Paraíba State, northeastern Brazil, and Paranaguá Bay, southern Brazil) it was attached alongside C. rhizophorae on mangrove tree roots. Due to their large phenotypic plasticity, it is very difficult to correctly identify even adult specimens of 
C. gasar and C. rhizophorae where they coexist. Hence, the confirmation, here, of the specific status of C. rhizophorae and C. gasar, the expansion of the known distribution of C. gasar to northern and northeastern Brazil, and the evidence of their occurrence in different habitats have important implications for biological and ecological studies of Latin American oysters. Due to their economic importance, the taxonomic separation of these oysters has consequences for biomonitoring and aquaculture programs (Ignacio et al. 2000, Rebelo et al. 2003).

A genetic study of allozymes from Crassostrea rhizophorae populations showed a weak genetic heterogeneity between populations near Rio de Janeiro (Southeast Brazil) and Paranaguá Bay (South Brazil) (Ignacio et al. 2000). Similar results were observed for other Crassostrea species (Buroker et al. 1979). However, the present analyses using a larger number of populations have unveiled significant intraspecific genetic differences both within C. rhizophorae and within C. gasar. Almost the same genetic partitioning detected by allozyme analyses of C. rhizophorae (one group in Panama and various in Brazil) and of C. gasar (at least one group each in northern/northeastern and south/southeastern Brazil) were also found by COI sequencing analyses.

There are many factors that can influence genetic population structure in marine organisms, including limited dispersal capability and the existence of extrinsic barriers to gene flow, such as temperature, salinity, and ocean currents (Launey et al. 2002), as well as historical factors, such as climate and marine current oscillations, and sea level changes (Rocha et al. 2008). Sampling strategies and genetic patchiness must also be taken into account (Arnaud-Haond et al. 2008).

Some intraspecific genetic differences have been observed in Crassostrea rhizophorae from the Caribbean (Hedgecock \& Okazaki 1984) and between Atlantic and Gulf of Mexico C. virginica (Hare \& Avise 1998, Varney et al. 2009). As the larvae of Crassostrea are planktonic and have great dispersal capability (for instance, $C$. virginica larvae can spend 2 to $3 \mathrm{wk}$ in the plankton; Kennedy 1996), the high levels of genetic differentiation found in these works and in the present study are surprising.

The isolation by distance observed here for Crassostrea rhizophorae and C. gasar indicates that restricted larval dispersal may be one of the factors responsible for the genetic structuring of these species. Isolation by distance has also been detected in other oyster species, such as Ostrea edulis (Launey et al. 2002), C. virginica (Rose et al. 2006), and C. ariakensis (Xiao et al. 2010).

Mismatch distribution analyses suggest that the population history of both species is characterized by expansion events, which are congruent with changes (ocean currents and sea levels) in the Late Pleistocene. Unfortunately, information about the biology of South American oyster species is still very scarce, which makes discussing the possible causes of the observed population heterogeneity difficult. Nevertheless, despite the factors responsible for the observed structuring patterns, our results show that those genetically distinct Crassostrea rhizophorae and C. gasar groups should be considered as discrete management units and this should be taken into account for future aquaculture programs and fisheries management of both resources, especially considering that these species usually display different growth rates and tolerances for temperature and salinity (Absher 1989, Melo et al. 2010b).

Acknowledgements. We thank T. Absher for invaluable discussions on oyster systematics and C. Melo for help in the identification of oysters, as well as $\mathrm{H}$. Cunha for helpful suggestions that improved an earlier version of the manuscript and F. Monteiro for providing sequencing support. We also thank A. Freire, A. Pereira, A. Puchnick Legat, B. Ignacio, C. Tureck, C. Zilberberg, D. Almeida, F. Nunes, J. Legat, M. Klautau, M. Miranda, M. Oliveira, M. Rebelo, N. Knowlton, P. Paiva, P. Vianna, S. Christo, and T. Absher for help with sample collection. This work is part of the PhD thesis of the first author at the Genetics Department of the Federal University of Rio de Janeiro (UFRJ) and was supported by grants from the Brazilian CAPES, CNPq, FAPERJ, FINEP, FUJB, MCT (CT-AGRO/CT-HIDRO), MPA, and PADCT.

\section{LITERATURE CITED}

Absher TM (1989) Populações naturais de ostras do gênero Crassostrea do litoral do Paraná - desenvolvimento larval, recrutamento e crescimento. PhD thesis, University of São Paulo

Arnaud-Haond S, Vonau V, Rouxel C, Bonhomme F, Prou J, Goyard E, Boudry P (2008) Genetic structure at different spatial scales in the pearl oyster (Pinctada margaritifera cumingii) in French Polynesian lagoons: beware of sampling strategy and genetic patchiness. Mar Biol 155: $147-157$

Batista FM, Leitão $A$, Huvet $A$, Lapègue $S$, Heurtebise $S$, Boudry P (2006) The taxonomic status and origin of the Portuguese oyster Crassostrea angulata (Lamark, 1819). Oyster Res Inst News 18:3-10

Belkhir K, Borsa P, Chikhi L, Raufaste N, Bonhomme F (2002) GENETIX 4.04, logiciel sous Windows pour la génétique des populations. Montpellier

> Boudry P, Heurtebise S, Collet B, Cornette F, Gerard A (1998) Differentiation between populations of the Portuguese oyster, Crassostrea angulata (Lamarck) and the Pacific oyster, Crassostrea gigas (Thünberg), revealed by mtDNA RFLP analysis. J Exp Mar Biol Ecol 226:279-291

Boudry P, Heurtebise S, Lapègue S (2003) Mitochondrial and nuclear DNA sequence variation of presumed Crassostrea gigas and C. angulata specimens: a new oyster species in Hong Kong? Aquaculture 228:15-25

Briggs JC (1974) Marine zoogeography. McGraw-Hill, New York

Buroker NE, Hershberger WK, Chew KK (1979) Population genetics of the family Ostreidae. II. Interspecific studies 
of the genera Crassostrea and Saccostrea. Mar Biol 54: $171-184$

Carranza A, Defeo O, Beck M (2009) Diversity, conservation status and threats to native oysters (Ostreidae) around the Atlantic and Caribbean coasts of South America. Aquat Conserv: Mar Freshw Ecosyst 19:344-353

Carriker MR, Gaffney PM (1996) A catalogue of selected species of living oysters (Ostreacea) of the world. In: Kennedy VS, Newell RIE, Eble AF (eds) The eastern oyster: C. virginica. Maryland Sea Grant College, Maryland, p 1-18

> Cenik C, Wakeley J (2010) Pacific salmon and the coalescent effective population size. PLoS ONE 5:e13019

> Clement M, Posada D, Crandall KA (2000) TCS: a computer program to estimate gene genealogies. Mol Ecol 9: $1657-1659$

> Demarcq H, Demarcq G (1992) The Crassostrea gasar (Bivalvia) biostrome of the Holocene from Sine-Saloum (Senegal) - new data and ecostratigraphical interpretation. Geobios 25:225-250

$>$ Dixon DR, Solé-Cava AM, Pascoe PL, Holland PWH (1995) Periostracal adventitious hairs on spat of the mussel Mytilus edulis. J Mar Biol Assoc UK 75:363-372

> Dupanloup I, Schneider S, Excoffier L (2002) A simulated annealing approach to define the genetic structure of populations. Mol Ecol 11:2571-2581

Eldon B, Wakeley J (2006) Coalescent processes when the distribution of offspring number among individuals is highly skewed. Genetics 172:2621-2633

Excoffier L, Laval G, Schneider S (2005) Arlequin ver. 3.0: an integrated software package for population genetics data analysis. Evol Bioinform Online 1:47-50

Fairbridge RW (1976) Shellfish-eating pre-ceramic Indians in coastal Brazil. Science 191:353-359

FAO (2010) Fishstat Plus 2.30: Universal software for fishery statistical time series. Fisheries Department, Fishery Information, Data and Statistics Unit, Rome

> Felsenstein J (1981) Evolutionary trees from DNA sequences: a maximum likelihood approach. J Mol Evol 17:368-376

> Folmer O, Black M, Hoeh W, Lutz R, Vrijenhoek R (1994) DNA primers for amplification of mitochondrial cytochrome $c$ oxidase subunit I from diverse metazoan invertebrates. Mol Mar Biol Biotechnol 3:294-299

Fu YX (1997) Statistical tests of neutrality of mutations against population growth, hitchhiking and background selection. Genetics 147:915-925

Gusmão J, Solé-Cava AM (2002) Um sistema de diagnóstico molecular para a identificação de espécies comerciais de camarões marinhos brasileiros. In: Blas I (ed) CIVA 2002 (www.civa2002.org), Zaragoza, p 754-764

> Gusmão J, Lazoski C, Monteiro FA, Solé-Cava AM (2006) Cryptic species and population structuring of the Atlantic and Pacific seabob shrimp species, Xiphopenaeus kroyeri (Heller 1862) and X. riveti (Bouvier 1907). Mar Biol 149: 491-502

Hare MP, Avise JC (1998) Population structure in the American oyster as inferred by nuclear gene genealogies. Mol Biol Evol 15:119-128

Harry HW (1985) Synopsis of supraspecific classification of living oysters (Bivalvia: Gryphaeidae and Ostreidae). Veliger 28:121-158

> Hasegawa M, Kishino H, Yano T (1985) Dating of the humanape splitting by a molecular clock of mitochondrial DNA. J Mol Evol 22:160-174

Hedgecock D (1994) Does variance in reproductive success limit effective population sizes of marine organisms? In: Beaumont AR (ed) Genetics and evolution of aquatic organisms. Chapman \& Hall, London, p 122-134

Hedgecock D, Okazaki NB (1984) Genetic diversity within and between populations of American oysters (Crassostrea). Malacologia 25:535-549

Hedgecock D, Launey S, Pudovkin AI, Naciri Y, Lapègue S, Bonhomme F (2007) Small effective number of parents $\left(N_{b}\right)$ inferred for a naturally spawned cohort of juvenile European flat oysters Ostrea edulis. Mar Biol 150:1173-1182

Hoover CA, Gaffney PM (2005) Geographic variation in nuclear genes of the eastern oyster Crassostrea virginica Gmelin. J Shellfish Res 24:103-112

Ignacio BL, Absher TM, Lazoski C, Solé-Cava AM (2000) Genetic evidence for the presence of two species of Crassostrea (Bivalvia: Ostreidae) on the coast of Brazil. Mar Biol 136:987-992

Jensen JL, Bohonak AJ, Kelley ST (2005) Isolation by distance, web service. BMC Genet 6:13

Johansson ML, Banks MA, Glunt KD, Hassel-Finnegan HM, Buonaccorsi VP (2008) Influence of habitat discontinuity, geographical distance, and oceanography on fine-scale population genetic structure of copper rockfish (Sebastes caurinus). Mol Ecol 17:3051-3061

Kennedy VS (1996) The biology of larvae and spat. In: Kennedy VS, Newell RIE, Eble AF (eds) The eastern oyster: Crassostrea virginica. Maryland Sea Grant College, Maryland, p 371-422

Kimura M (1980) A simple method for estimating evolutionary rates of base substitutions through comparative studies of nucleotide sequences. J Mol Evol 16:111-120

Kirby MX (2000) Paleoecological differences between Tertiary and Quaternary Crassostrea oysters, as revealed by stable isotope sclerochronology. Palaios 15:132-141

Kirby MX (2001) Differences in growth rate and environment between Tertiary and Quaternary Crassostrea oysters. Paleobiology 27:84-103

Kirby MX, Jackson JBC (2004) Extinction of a fast-growing oyster and changing ocean circulation in Pliocene tropical America. Geology 32:1025-1028

Komatsu T, Chinzei K, Zakhera MS, Matsuoka H (2002) Jurassic soft-bottom oyster Crassostrea from Japan. Palaeontology 45:1037-1048

Lapègue S, Boutet I, Leitão A, Heurtebise S, Garcia P, ThiriotQuiévreux C, Boudry P (2002) Trans-Atlantic distribution of a mangrove oyster species revealed by $16 \mathrm{~S}$ mtDNA and karyological analyses. Biol Bull 202:232-242

Launey S, Ledu C, Boudry P, Bonhomme F, Naciri-Graven Y (2002) Geographic structure in the European flat oyster (Ostrea edulis L.) as revealed by microsatellite polymorphism. J Hered 93:331-338

Lawrence DR (1995) Diagnosis of the genus Crassostrea (Bivalvia, Ostreidae). Malacologia 36:185-202

Lazoski C (2004) Sistemática molecular e genética populacional de ostras brasileiras (Crassostrea spp.). PhD thesis, Federal University of Rio de Janeiro

Lazoski C, Solé-Cava AM, Boury-Esnault N, Klautau M, Russo CAM (2001) Cryptic speciation in a high gene flow scenario in the oviparous marine sponge Chondrosia reniformis. Mar Biol 139:421-429

Leitão A, Chaves R, Santos S, Guedes-Pinto H, Boudry P (2007) Interspecific hybridization in oysters: restriction enzyme digestion chromosome banding confirms Crassostrea angulata $\times$ C. gigas F1 hybrids. J Exp Mar Biol Ecol 343:253-260

Littlewood DTJ (1994) Molecular phylogenetics of cupped oysters based on partial 28S rRNA gene sequences. Mol Phyl Evol 3:221-229

Manchenko GP (1994) A handbook of detection of enzymes on electrophoretic gels. CRC Press, London

> Marko PB (2002) Fossil calibration of molecular clocks and the divergence times of geminate species pairs separated by 
the Isthmus of Panama. Mol Biol Evol 19:2005-2021

Melo AGC, Varela ES, Beasley CB, Schneider H and others (2010a) Molecular identification, phylogeny and geographic distribution of Brazilian mangrove oysters (Crassostrea). Genet Mol Biol 33:564-572

Melo CMR, Solé-Cava AM, Lazoski C (2010b) Crassostrea gigas in natural oyster banks in southern Brazil. Biol Invasions 12:441-449

Milbury CA, Gaffney PM (2005) Complete mitochondrial DNA sequence of the eastern oyster Crassostrea virginica. Mar Biotechnol 7:697-712

Moreau D (2001) Etude de génétique des populations sur l'huître creuse de mangrove, Crassostrea gasar (Adanson, 1757), par l'apport du marqueur ITS2. Diplôme d'Etudes approfondies en Biologie des Populations et écosystèmes. Université de Sciences la Rochelle, France

Nei M (1978) Estimation of average heterozygosity and genetic distance from a small number of individuals. Genetics 89:583-590

Nei M (1987) Molecular evolutionary genetics. Columbia University Press, New York

> Nielsen R, Wakeley J (2001) Distinguishing migration from isolation: a Markov chain Monte Carlo approach. Genetics 158:885-896

Ó Foighil D, Marshall BA, Hilbish TJ, Pino MA (1999) TransPacific range extension by rafting is inferred for the flat oyster Ostrea chilensis. Biol Bull 196:122-126

Ó Foighil D, Taylor DJ (2000) Evolution of parental care and ovulation behavior in oysters. Mol Phyl Evol 15:301-313

Palumbi SR (1996) Nucleic acids II: The polymerase chain reaction. In: Hillis DM, Moritz C (eds) Molecular systematics. Sinauer Associates, Massachusetts, p 205-247

- Palumbi SR (2003) Population genetics, demographic connectivity, and the design of marine reserves. Ecol Appl 13: S146-S158

Pie MR, Ribeiro RO, Boeger WA, Ostrensky A, Falleiros RM, Angelo L (2006) A simple PCR-RFLP method for the discrimination of native and introduced oyster species (Crassostrea brasiliana, C. rhizophorae and C. gigas; Bivalvia: Ostreidae) cultured in Southern Brazil. Aquacult Res 37: $1598-1600$

Posada D, Crandall KA (1998) MODELTEST: testing the model of DNA. Bioinformatics 14:817-818

Rebelo MF, Pfeiffer WC, da Silva H, Moraes MO (2003) Cloning and detection of metallothionein mRNA by RTPCR in mangrove oysters (C. rhizophorae). Aquat Toxicol 64:359-362

Reece KS, Cordes JF, Stubbs JB, Hudson KL, Francis EA (2008) Molecular phylogenies help resolve taxonomic confusion with Asian Crassostrea oyster species. Mar Biol 153: 709-721

Rios EC (1994) Seashells of Brazil. FURG, Rio Grande

> Rocha LA, Rocha CR, Robertson DR, Bowen BW (2008) Comparative phylogeography of Atlantic reef fishes indicates both origin and accumulation of diversity in the Caribbean. BMC Evol Biol 8:157

Rogers AR, Harpending HC (1992) Population growth makes waves in the distribution of pairwise genetic differences. Mol Biol Evol 9:552-569

Rose CG, Paynter KT, Hare MP (2006) Isolation by distance in the eastern oyster, Crassostrea virginica, in Chesapeake Bay. J Hered 97:158-170

Saitou N, Nei M (1987) The neighbor-joining method: a new method for reconstructing phylogenetic trees. Mol Biol Evol 4:406-425
Sandison EE, Hill MB (1966) The distribution of Balanus pallidus stutsburi Darwin, Gryphaea gasar ((Adanson) Dautzenberg), Mercierella enigmatica Fauvel and Hydroides uncinata (Philippi) in relation to salinity in Lagos Harbour and adjacent creeks. J Anim Ecol 35:235-250

Singarajah KV (1980) On the taxonomy, ecology and physiology of a giant oyster, Crassostrea paraibanensis, new species. Bull Mar Sci 30:833-841

Sohl NF, Kauffman EG (1964) Giant upper Cretaceous oysters from the Gulf coast and Caribbean. US Geol Surv Prof Pap 483:1-22

Stenzel HB (1971) Bivalvia Mollusca: oysters. In: Moore RC (ed) Treatise on invertebrate paleontology. GSAUniversity of Kansas Press, Lawrence, p 953-1217

Swofford DL (1998) PAUP. Phylogenetic analysis using parsimony, version 4. Sinauer Associates, Sunderland, MA

Swofford DL, Selander RB (1981) BIOSYS-1, a FORTRAN programme for the comprehensive analysis of electrophoretic data in population genetics and systematics. J Hered 72: 281-283

> Tajima F (1989) Statistical method for testing the neutral mutation hypothesis by DNA polymorphism. Genetics 123:585-595

- Tamura K, Dudley J, Nei M, Kumar S (2007) MEGA4: Molecular evolutionary genetics analysis (MEGA) software version 4.0. Mol Biol Evol 24:1596-1599

Templeton AR, Crandall KA, Sing CF (1992) A cladisticanalysis of phenotypic associations with haplotypes inferred from restriction endonuclease mapping and DNAsequence data. 3. Cladogram estimation. Genetics 132: 619-633

> Thompson JD, Gibson TJ, Plewniak F, Jeanmougin F, Higgins DG (1997) The ClustalX Windows interface: flexible strategies for multiple sequence alignment aided by quality analysis tools. Nucleic Acids Res 25:4876-4882

Valentine JW, Jablonski D, Kidwell S, Roy K (2006) Assessing the fidelity of the fossil record by using marine bivalves. Proc Natl Acad Sci USA 103:6599-6604

- Varela ES, Beasley CR, Schneider H, Sampaio I, MarquesSilva NS, Tagliaro CH (2007) Molecular phylogeny of mangrove oysters (Crassostrea) from Brazil. J Mollusc Stud 73:229-234

> Varney RL, Galindo-Sanchez CE, Cruz P, Gaffney PM (2009) Population genetics of the eastern oyster Crassostrea virginica (Gmelin, 1791) in the Gulf of Mexico. J Shellfish Res 28:855-864

Verdon B (2000) Phylogéographie des huîtres creuses des mangroves de l'Atlantique Sud par l'apport des marqueurs moléculaires. Diplôme d'Etudes Approfondies en Biologie des Populations et Ecosystèmes. Université de Sciences La Rochelle, France

- Waples RS (1987) A multispecies approach to the analysis of gene flow in marine shore fishes. Evolution 41:385-400

Williams ST, Knowlton N, Weigt LA, Jara JA (2001) Evidence for three major clades within the snapping shrimp genus Alpheus inferred from nuclear and mitochondrial gene sequence data. Mol Phyl Evol 20:375-389

Wright S (1978) Evolution and the genetics of populations, Vol 4. The University of Chicago Press, London

> Wu X, Xu X, Yu Z, Wei Z, Xia J (2010) Comparison of seven Crassostrea mitogenomes and phylogenetic analyses. Mol Phyl Evol 57:448-454

- Xiao J, Cordes JF, Wang H, Guo X, Reece KS (2010) Population genetics of Crassostrea ariakensis in Asia inferred from microsatellite markers. Mar Biol 157:1767-1781

Submitted: September 15, 2010; Accepted: January 14, 2011

Proofs received from author(s): March 18, 2011 